
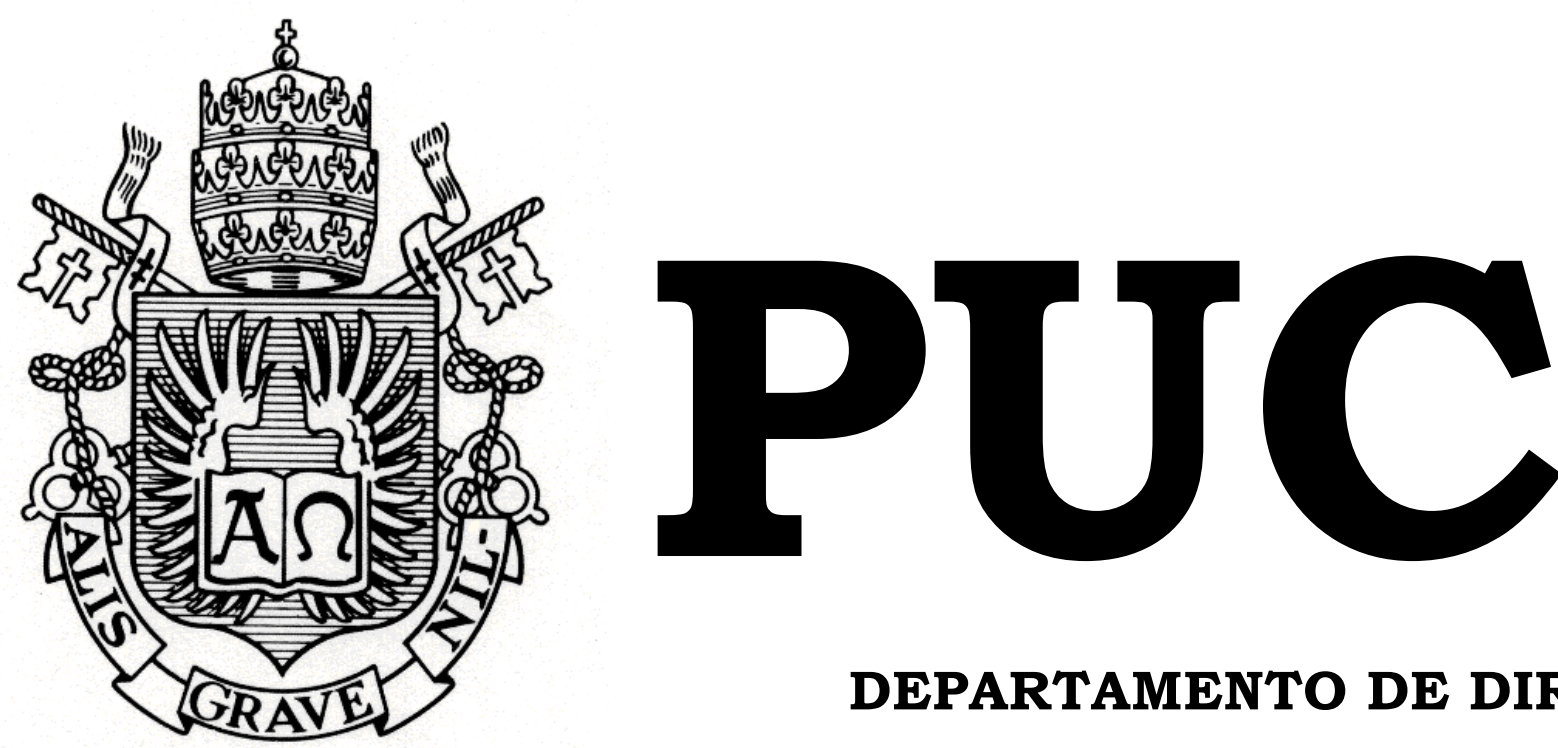

DEPARTAMENTO DE DIREITO

\title{
AS DIFICULDADES DE EFETIVAÇÃO DA COTA DE PESSOAS COM DEFICIÊNCIA PARA EMPRESAS PRIVADAS PREVISTA NA LEI No 8.213/91: UMA ANÁLISE CRÍTICA
}

por

RAPHAEL LINS DE ALMEIDA

ORIENTADOR(A): IRINEU ZIBORDI

2011.2

PONTIFÍCIA UNIVERSIDADE CATÓLICA DO RIO DE JANEIRO

RUA MARQUÊS DE SÃO VICENTE, 225 - CEP 22453-900

RIO DE JANEIRO - BRASIL 


\section{AS DIFICULDADES DE EFETIVAÇÃO DA COTA DE PESSOAS COM DEFICIÊNCIA PARA EMPRESAS PRIVADAS PREVISTA NA LEI No 8.213/91: UMA ANÁLISE CRÍTICA}

por

RAPHAEL LINS DE ALMEIDA

\begin{abstract}
Monografia apresentada ao Departamento de Direito da Pontificia Universidade Católica do Rio de Janeiro (PUC-Rio) como requisito parcial para obtenção do Título de Bacharel em Direito.
\end{abstract}

Orientador(a): Irineu Zibordi 


\section{RESUMO}

Este trabalho propõe-se a fazer uma análise crítica do art.93 da lei 8.213/91, dispositivo legal que prevê a reserva de vagas em empresas privadas para pessoas portadoras de deficiência. Através de pesquisa bibliográfica e jurisprudencial e da análise de dados do mercado de trabalho, pretendemos demonstrar as dificuldades encontradas para se atingir a intenção da lei de incluir as pessoas com deficiência no mercado de trabalho. Apontamos as lacunas e falhas da legislação que, entendemos, são as verdadeiras responsáveis pela dificuldade de inserção de portadores de necessidades especiais no mercado de trabalho de forma efetiva e inclusiva.

O trabalho monográfico pretende ser crítico e envereda por uma arena pouquíssimo trabalhada academicamente. São raros os trabalhos críticos ao dito dispositivo legal, que buscam encontrar as falhas e apontar possíveis caminhos. Esse trabalho tem a pretensão de, ao menos academicamente, contribuir para a discussão e o debate nesse sentido.

\section{PALAVRAS-CHAVE}

Pessoas com deficiência, empregabilidade, empresas, cota, reserva de vagas, ação afirmativa, crítica, emprego, trabalho. 
Aos meus pais. Sem eles nada seria possível.

"Nunca se afaste dos seus sonhos, pois se eles se forem você continuará vivendo, mas terá deixado de existir" Charles Chaplin 


\section{SUMÁRIO}

SUMÁRIO

INTRODUÇÃO 5

CAPÍTULO I - O CONCEITO DE PORTADOR DE DEFICIÊNCIA ................................................. 9

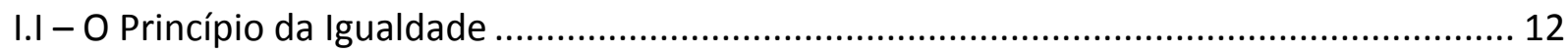

CAPÍTULO II -AÇÕES AFIRMATIVAS E DISCRIMINAÇÕES LÍCITAS .......................................... 16

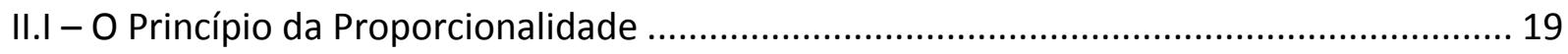

CAPÍTULO III - A COTA DO ART. 93 DA LEI 8.213/91 ................................................................. 23

III. I - A cota do art.93 da lei 8.213/91 e a empregabilidade da pessoa com deficiência........ 26

CAPÍTULO IV - ANÁLISE CRÍTICA DO ART.93 DA LEI 8.213/91: AS DIFICULDADES DE EFETIVAÇÃO

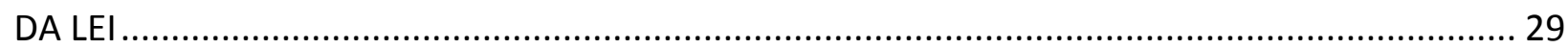

IV.I - A não diferenciação das empresas por ramo de atividade............................................ 29

IV.II - A falta de profissionais qualificados no mercado de trabalho...................................... 33

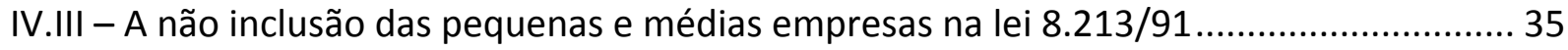

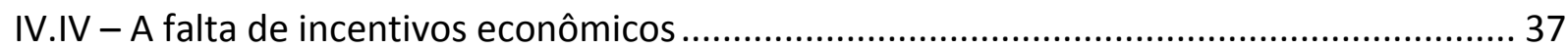

IV.V - A inexistência de regras para a (re)colocação no mercado de trabalho ....................... 39

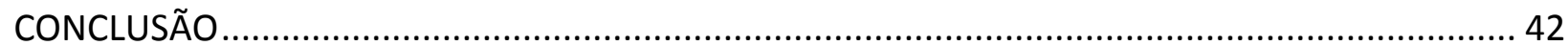

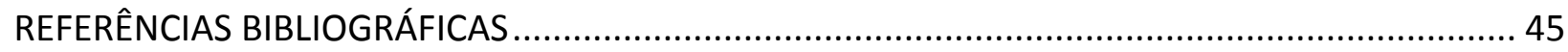


LISTA DE TABELAS

Tabela 1

Tabela 2 26

Tabela 3 27

Tabela 4 27 


\section{INTRODUÇÃO}

O grupo de pessoas portadoras de necessidades especiais é expressivo, porém, é um grupo marginalizado que merece uma atenção especial do Estado. Segundo dados do Censo 2010 realizado pelo Instituto Brasileiro de Geografia e Estatística (IBGE) 15\% da população brasileira é portadora de algum tipo de necessidade especial, o que significa mais de 28 milhões de brasileiros. Mas, segundo estimativas do próprio IBGE, somente 5\% (pouco mais de 1,4 milhão) dessas pessoas estão empregadas.

A Declaração de Madrid de 1992, aprovada no 10 Congresso Europeu de Pessoas com Deficiência, preceitua a não discriminação combinada com ações positivas como receita para a inclusão social dos portadores de necessidades especiais. A deficiência é encarada como uma questão de direitos humanos, observada sobre o prisma da igualdade de direitos de modo que os cidadãos deficientes não sejam marginalizados mas incluídos na sociedade com igualdade de oportunidades.

Nesse diapasão, a questão do emprego desponta como essencial na busca pela dita inclusão social. A promoção do acesso de pessoas deficientes ao mercado de trabalho surge como uma das formas mais importantes de se combater a exclusão social das pessoas com deficiência bem como de promover a sua dignidade e independência. Ações afirmativas no sentido de incluir os portadores de deficiência no mercado de trabalho em igualdade de condições com todos os demais cidadãos devem ser encorajadas e estimuladas pelos Estados. Antes mesmo da Declaração de Madrid, a Resolução no 30/84 aprovada pela Organização das Nações Unidas em 09/12/1975 intitulada “Declaração dos Direitos das Pessoas Deficientes" já previa o trabalho e o emprego como questão chave, in verbis:

"7 - As pessoas deficientes têm direito à segurança econômica e social a um nível de vida decente e, de acordo com suas capacidades, a obter e manter um emprego ou desenvolver atividades úteis, produtivas e remuneradas e a participar dos sindicatos."

Porém, existe uma latente desigualdade que marca as relações de emprego, aonde temos de um lado a força do empregador e seu objetivo de lucro e de outro os interesses dos empregados. Tal relação deve ainda ser compatibilizada com as necessidade sociais, dentre elas a inclusão das minorias. Na tentativa de se equilibrar essa relação, os direitos do trabalhador são reconhecidos e positivados pelo Estado de modo que o próprio Estado possa zelar pela igualdade e dignidade nas relações de 
trabalho. E para compatibilizar essa relação com as necessidades da sociedade surgem também leis que visam a inclusão social, como leis que buscam incluir deficientes e leis que buscam incluir jovens no mercado de trabalho (lei de aprendizagem, por exemplo).

Esse trabalho propõe se ater ao primeiro caso, mais especificamente à lei no 8.213 de 1991 que trouxe em seu art.93 uma política pública de cotas para pessoas com deficiência com vistas a se tornar um instrumento de inclusão social das pessoas portadoras de algum tipo de deficiência. O dito dispositivo legal impõe que as empresas privadas contratem pessoas portadoras de deficiência de maneira que representem um percentual de 2 (dois) a 5\% (cinco por cento) do total de empregados da empresa, dependendo do número de empregados que a empresa possui.

Ocorre que essa porcentagem não diferencia cargo ou função nem tampouco o ramo de atuação da empresa. A lei é taxativa, direta, quase matemática. Prevê apenas números e percentuais, não tendo o cuidado de diferenciar a atividade a ser desenvolvida. Pode acontecer, portanto, do empregador contratar todos os empregados deficientes para exercer uma única função, o que é muito comum. A empresa cumpre a cota mas se afasta da finalidade da lei de incluir o portador de necessidade especial (PNE) no mercado de trabalho.

Além disso, deve-se levar em conta a qualificação do profissional com deficiência, questão não aventada nem de longe pela lei. Não se prevê nenhum tipo de estrutura estatal para a qualificação do profissional portador de deficiência, fazendo com que estes tenham muita dificuldade de se qualificar e de outro modo que as empresas tenham muita dificuldade em contratar.

A lei também não diferencia as empresas por ramo de atuação, o que tem motivado decisões judiciais que anulam multas aplicadas a algumas empresas que exercem atividades incompatíveis com a porcentagem de cargos prevista em lei para portadores com deficiência.

Este trabalho, portanto, procura apontar críticas à lei e a sua aplicação questionando se a finalidade da lei realmente é atingida da maneira como foi intentado. Para tanto, precisamos identificar quem são os deficientes, quais os seus direitos positivados na legislação brasileira, quais as descriminações que sofrem, qual o remédio 
legal para tal e a adequação da lei com o objetivo de inclusão social no mercado de trabalho.

Na primeira parte o trabalho se preocupa em definir o seu objeto de estudo, qual seja, as pessoas portadoras de deficiência. Procura-se definir quem são essas pessoas através de um breve histórico para que seja possível se chegar a definição contemporânea do que se entende por portador de necessidade especial. Ainda nessa primeira parte o trabalho fará uma exposição sobre o princípio constitucional da igualdade, diferenciando a igualdade formal da igualdade material para que se possa entender porque a própria igualdade é o fundamento jurídico de ações afirmativas como a prevista na lei $n=8.213 / 91$.

A segunda parte do presente estudo se preocupa com as ações afirmativas e a sua licitude. As ações afirmativas representam a forma como o Estado busca atingir a igualdade material dos cidadãos, a igualdade de oportunidades. Portanto, serão analisadas os tipos de discriminações aceitáveis pelo Direito e será buscado o fundamento jurídico das ações afirmativas. Serão apresentadas as ideias da doutrina sobre assunto bem como o entendimento do Poder Judiciário e a sua compatibilização com o princípio da proporcionalidade.

A terceira parte do trabalho versará exclusivamente sobre a cota prevista no art.93 da lei no 8.213/91 para pessoas portadoras de deficiência. Será realizado um estudo específico sobre o dispositivo legal e a interpretação que o Judiciário trabalhista o tem emprestado. Ainda nessa parte, o trabalho traz dados sobre a empregabilidade da pessoa com deficiência e aponta já algumas inoperâncias da lei.

A quarta parte busca analisar de maneira crítica a lei, trazendo a tona a discussão dos pontos que entendemos como lacunas legais. Serão apontadas as falhas que entendemos que contribuem para a notória dificuldade de se efetivar a reserva legal prevista no art.93 da lei no 8.213/91. Serão apresentadas alternativas, ações que entendemos adequadas e eficazes para promoção do direito ao trabalho desse grupo de pessoas.

As fontes do estudo serão a legislação nacional, livros, artigos e matérias sobre ações afirmativas, cotas de pessoas com deficiência e a questão da empregabilidade 
dessas pessoas. Também servirão como base de dados algumas informações sobre o mercado de trabalho do Ministério do Trabalho e Emprego e os dados do Censo 2010 do Instituto Brasileiro de Geografia e Estatística. Também teremos como fonte a jurisprudência do Tribunal Superior do Trabalho, Supremo Tribunal Federal e Tribunais Regionais do Trabalho sobre o assunto.

A bibliografia sobre o assunto, importante notar, é muito vaga e limitada. Obras dedicadas ao tema da reserva de vagas de portadores de deficiência são poucas e menos ainda são aquelas que a criticam. Por isso, esse trabalho não se limita a ser um trabalho descritivo mas também se encobre de um aspecto propositivo ao ter a pretensão, na quarte parte do estudo, de analisar a cota de uma forma crítica e propor algumas sugestões que entendemos adequadas para a solução dos problemas apontados. 


\section{CAPÍTULO I - O CONCEITO DE PORTADOR DE DEFICIÊNCIA}

Preliminarmente, faz-se necessário delimitar quem são os sujeitos que fazem parte do conceito de deficientes e, portanto, os sujeitos abrangidos pela Lei no 8.213/91. Cumpre notar que o beneficiário da Previdência Social reabilitado também é destinatário da Lei em questão, no entanto, esse sujeito não será objeto de estudo nesse trabalho. Focaremos na pessoa portadora de deficiência.

Em uma análise histórica podemos observar que o tratamento dispensado aos deficientes era algo desumano. Em Esparta eram eliminados, em Roma as crianças deformadas eram abandonadas. Platão, em A República, escreveu

"Pegarão então os filhos dos homens superiores, e levá-los-ão para o aprisco, para junto de amas que moram à parte num bairro da cidade, os dos homens inferiores, e qualquer dos outros que seja disforme, escondê-los-ão num lugar interdito e oculto, como convém."

Mais tarde com o Cristianismo os portadores de deficiência passaram a ser tratados ora com caridade ora com uma certa dose de extermínio para teoricamente expurga-lhes os pecados. A partir do século XVIII e com a Revolução Francesa a deficiência passou a ser vista como um problema médico tratável. Surgem hospitais psiquiátricos, conventos, asilos e outras instituições que destinavam-se a tratar pessoas com deficiência. Nessa época também surge o método de leitura Braile para os deficientes visuais, inventado em 1827 pelo francês Louis Braille.

Já no século XX após as Guerras e após diversas Resoluções e Declarações de Direitos Humanos das Nações Unidas, a ONU proclama a primeira Declaração Internacional especificamente direcionada a deficientes. Trata-se da Resolução № 2.856 de 1971 intitulada Declaração dos Deficientes Mentais direcionada especificamente aos direitos das pessoas portadoras de doenças mentais e correlatas. Visa conceder aos deficientes mentais os mesmos direitos concedidos a todos os seres humanos, admitindo limitação a esses direitos somente quando efetivamente comprovada a necessidade, mediante avaliação técnica criteriosa. A limitação ou suspensão do direito dessas pessoas somente pode ocorrer mediante um processo que inclua salvaguardas ao deficiente e que preveja avaliações periódicas e o direito do deficiente apelar contra a restrição a instâncias superiores.

Alguns anos mais tarde temos a Resolução no 30/84 também da ONU que traz a Declaração dos Direitos das Pessoas Portadoras de Deficiência. Tal resolução assim define o portador de deficiência em seu art1ㅇ: 
"O termo pessoa portadora de deficiência, identifica aquele indivíduo que, devido a seus déficits físicos ou mentais, não está em pleno gozo da capacidade de satisfazer, por si mesmo, de forma total ou parcial, suas necessidades vitais e sociais, como faria um ser humano normal."

A Organização Internacional do Trabalho (OIT) também tratou do assunto na Convenção 159 de 1963 que recomenda que os países membros da OIT considerem que o objetivo da readaptação profissional é permitir que pessoas com deficiência consigam e mantenham um emprego conveniente, progridam profissionalmente e, em consequência, tenham facilitada sua inserção ou reinserção na sociedade. A Convenção 159 da OIT foi internalizada na legislação brasileira através do Decreto no 129/91 e define pessoa deficiente no seu art.1으 como "todas as pessoas cujas possibilidades de obter e conservar um emprego adequado e de progredir no mesmo fiquem substancialmente reduzidas devido a uma deficiência de caráter física ou mental devidamente comprovada".

Nesse contexto, tivemos também no Brasil o Decreto n $3.298 / 99$ atualizado pelo Decreto no 5.926/04 que em seu art.3o assim define deficiência:

“Art. 3ㅇ Para os efeitos deste Decreto, considera-se:

I - deficiência - toda perda ou anormalidade de uma estrutura ou função psicológica, fisiológica ou anatômica que gere incapacidade para o desempenho de atividade, dentro do padrão considerado normal para o ser humano;"

Cumpre notar que a Lei no 8.213/91, foco deste trabalho, não traz qualquer definição sobre o que seria portador de deficiência. Portanto, ficávamos, no Brasil, com a definição apresentada pelo Decreto no $3.298 / 99$ combinada com a definição do Decreto no 129/91 que internalizou a Convenção 159 da OIT.

Porém, podemos perceber que todas as definições supra comentadas tratam a questão da deficiência sob o prisma da incapacidade do indivíduo, nomeadamente suas anormalidades físicas ou psíquicas. As definições desconsideram os aspectos da inadequação dos deficientes ao meio social e a sociedade em que vivem, conferindo maior importância a questões médicas e clínicas. Ou seja, a deficiência decorre unicamente das limitações físicas ou psíquicas do indivíduo.

No entanto, tais definições são insuficientes na medida em que não consideram questões como o desenvolvimento tecnológico e não definem claramente o que seria um "padrão considerado normal para o ser humano". Sobre esse último aspecto não há consenso 
médico ou psicológico sobre o que seria um ser humano "normal", o que torna a expressão da lei um termo jurídico indefinido e impreciso. Sobre o desenvolvimento da tecnologia, o legislador deveria atentar para o fato que muitas vezes a tecnologia disponível acaba por eliminar a limitação do antes deficiente, fazendo sumir o déficit de função física que acaba compensado pelo uso de algum equipamento ou instrumento tecnológico.

Dessa maneira, se esse déficit for eliminado a ponto de fazer com que o antes deficiente agora tenha igualdade de condições com qualquer outra pessoa, temos que ações afirmativas passam a ser dispensáveis posto que injustas. Portanto temos que

“(...) ao menos para o direito, o que importa não é o atributo em si da pessoa portadora de déficit (por exemplo, a perda da visão, a dificuldade de locomoção), mas sim a redução da capacidade de integração ao meio que deste deriva. (...) A ideia central, portanto, é a de que as pessoas não são, por si sós, deficientes; a sociedade é que produz a deficiência, em um processo cultural de exclusão. (...) Deficiência, portanto, não é algo que alguém tem. Deficiência é a redução da capacidade de integração ao meio, motivada pela inadaptação dos serviços ou bens, públicos e particulares, às necessidades especiais de pessoas que apresentam alterações em funções orgânicas ou mentais." ${ }^{1}$

Oportunamente, temos no Brasil outra norma internacional devidamente ratificada, o que Ihe confere status de lei nacional que é a Convenção Interamericana para a Eliminação de todas as formas de Discriminação contra as Pessoas Portadoras de Deficiência (Convenção da Guatemala) promulgada pelo Decreto no 3.956 de 08 de outubro de 2001 que trouxe uma nova definição de deficiência em consonância com o entendimento aqui apresentado, revogando a definição do art.3ำ do Decreto no 3.298/99, in verbis:

"O termo 'deficiência' significa uma restrição física, mental ou sensorial, de natureza permanente ou transitória, que limita a capacidade de exercer uma ou mais atividades essenciais da vida diária, causada ou agravada pelo ambiente econômico e social." (grifo meu)

É o entendimento que vigora hoje, reforçado ainda pelo Decreto no 6.949/09 que promulgou a Convenção Internacional sobre os direitos das Pessoas com deficiência, assinada em Nova York, em 30 de março de 2007 que trouxe a seguinte definição de deficiência:

\footnotetext{
"Pessoas com deficiência são aquelas que têm impedimentos de longo prazo de natureza física, mental, intelectual ou sensorial, os quais, em interação com diversas barreiras, podem obstruir sua participação plena e efetiva na sociedade em igualdade de condições com as demais pessoas".
}

\footnotetext{
${ }^{1}$ SILVA, Alexandre Vitorino. Direitos a prestações positivas e igualdade: a deficiência São Paulo: LTr, 2007.
} 
Apesar do entendimento em consonância com a mais respeitável doutrina, o referido decreto restringiu um pouco o rol de pessoas abrangidas pela definição ao inserir a expressão "impedimentos de longo prazo". Salvo melhor juízo, entendemos que nesse campo dos direitos humanos nossa Constituição não admite a reformatio in pejus e, portanto, tal expressão deve ser desconsiderada para fins de apreciação da existência de deficiência, devendo ser considerado deficiente também aqueles que apresentam impedimentos transitórios enquanto mantiveram tal condição, conforme prevê o Decreto no 3.956/01.

Sobre a classificação das deficiências e as características que possibilitam enquadrá-las pelas empresas e médicos do trabalho, temos diversos Decretos e Portarias do Ministério do Trabalho e do Ministério da Previdência Social, entre eles o de maior importância o Decreto no 5.296/04 que define deficiências físicas, auditivas, visuais e mentais e suas características.

Por fim, quanto à designação encontramos em nossa Constituição alguns termos recorrentes como: pessoa portadora de deficiência (Art. 23, II; 24, XIV; 37, VIII; 203, IV); portador de deficiência (Art. 7ำ XXXI; 208, III) ou portador de deficiência física, sensorial ou mental (Art. 227, II). No entanto, doutrinadores propõe o uso de termos como pessoa com deficiência; pessoa que tem deficiência física, auditiva, visual ou mental. ${ }^{2} \mathrm{O}$ uso de siglas, de outro modo, costuma ser rechaçado por muitos, apesar do uso corriqueiro de insígnias como PPD (pessoa portadora de deficiência) e PNE (pessoa portadora de necessidades especiais). tema não merecerá muito de nossa atenção face a sua pouca importância para o objetivo do trabalho e à falta de consenso na comunidade sobre o assunto.

\section{I.I - O Princípio da Igualdade}

A Constituição de 1988 em seu art.5ํ, caput, traz insculpido o princípio da igualdade de direitos prevendo uma virtual igualdade de possibilidades, ou seja, prevendo que todos os cidadãos tem direito a um tratamento idêntico pela lei. É a chamada igualdade formal segundo a qual "todos são iguais perante a lei". Porém, essa é uma denominação genérica e abstrata que não reconhece a diversidade e a pluralidade da sociedade.

A igualdade deve ser observada em consonância com os critérios albergados pelo ordenamento jurídico de forma que a diversidade da sociedade seja respeitada. É salutar o

\footnotetext{
${ }^{2}$ GUGEL, Maria Aparecida. Pessoas com deficiência e o direito ao trabalho. Florianópolis: Obra jurídica, 2007. P. 83.
} 
reconhecimento de que existem parcelas da sociedade que não possuem as mesmas condições ou oportunidades e que, portanto, merecem uma tutela específica do Estado.

Dessa forma, vedam-se discriminações absurdas e diferenciações arbitrárias, porém, admite-se o tratamento desigual dos casos desiguais na medida em que se desigualam. Esse tratamento desigual daqueles que são desiguais é, na verdade, nas palavras de Moraes (2006):

“(...) exigência tradicional do próprio conceito de Justiça, pois o que realmente protege são certas finalidades, somente se tendo por lesado o princípio constitucional quando o elemento discriminador não se encontra a serviço de uma finalidade acolhida pelo Direito". ${ }^{3}$

As diferenciações previstas em lei devem contar com justificativas objetivas e razoáveis para que não sejam consideradas discriminatórias. Deve haver uma razoável proporcionalidade entre os meios empregados e a finalidade perseguida pela lei, em consonância com os direitos e garantias constitucionais fundamentais. Assim, os tratamentos normativos diferenciados são compatíveis com a Constituição quando verificada a existência de uma finalidade razoavelmente proporcional ao fim visado. ${ }^{4}$

Temos então ampla aceitação daquilo que chamamos de igualdade material. O princípio da igualdade material, chamado por alguns de princípio da inclusão, visa incluir aqueles que estão excluídos, por qualquer motivo, do pleno exercício de direitos garantidos a todos. Tal igualdade de oportunidades será obtida senão somente com políticas públicas, leis e programas de ação estatal. ${ }^{5}$ A igualdade exige, portanto, que além de não discriminar injustificadamente, o Estado deve atuar positivamente no sentido de promover a igualdade material que enderecem as peculiaridades dos grupos menos favorecidos e mitiguem ou eliminem desigualdades resultantes de processos históricos ou de sedimentação cultural de preconceitos.

Dessa maneira, as pessoas com deficiência enquanto grupo minoritário e notoriamente desfavorecido, merecem atenção especial do Estado para que possam competir em pé de igualdade e usufruir dos mesmos direitos garantidos a toda a sociedade. Devemos admitir que determinados grupos, como as pessoas com deficiência, estão em condição inferior e têm maior dificuldade de fruir de determinados direitos, como ocorre com o acesso ao mercado de

\footnotetext{
${ }^{3}$ MORAES, Alexandre de. Direito Constitucional. São Paulo: Atlas, 2006. P.31.

${ }^{4}$ BANDEIRA DE MELLO, Celso Antonio. Princípios da isonomia: desequiparações proibidas e permitidas. Revistra Trimestral de Direito Público, no1, p.79.

${ }^{5}$ COMPARATO, Fábio Konder. Direito público: estudos e pareceres. São Paulo: Saraiva, 1996. P.59.
} 
trabalho. Enquanto o conceito formal de igualdade não reconhece essas diferenças, a concepção material de igualdade utiliza como pressuposto justamente a diversidade.

\begin{abstract}
“No dizer de Dray, 'paulatinamente, porém, a concepção de uma igualdade puramente formal, assente no princípio geral da igualdade perante a lei, começou a ser questionada, quando se constatou que a igualdade de direitos não era, por si só, suficiente para tornar acessíveis a quem era socialmente desfavorecido as oportunidades de que gozavam os indivíduos socialmente privilegiados. Importaria, pois, colocar os primeiros ao mesmo nível de partida. Em vez de igualdade de oportunidades, importava falar em igualdade de condições'. Imperiosa, portanto, era a adoção de uma concepção substancial da igualdade, que levasse em conta em sua operacionalização não apenas certas condições fáticas e econômicas, mas também certos comportamentos inevitáveis da convivência humana, como é o caso da discriminação." ${ }^{6}$
\end{abstract}

Portanto, temos que partir do pressuposto que determinados grupos, por estarem em condições inferiores, tem maior dificuldade de fruir de determinados direitos. Sendo assim, a igualdade de direitos não poderá ser obtida senão com políticas públicas onde o Estado, ativamente, busca mitigar essa desigualdade.

"Fica claro, portanto, que não mais bastava a previsão geral de igualdade perante a lei, mas era necessário vincular o legislador, o administrador público a programas constitucionais cujo escopo era a inserção de tais pessoas nas escolas, universidades, serviço público e trabalho privado. $O$ direito à igualdade, a grande matriz de todas as políticas do Estado Social, dava origem, assim, lentamente, ao direito à inclusão das pessoas portadoras de deficiência, uma versão especializada da igualdade voltada para minimizar a exclusão criada pela compleição". ${ }^{7}$

Nesse diapasão, temos a lei que esse trabalho pretende analisar que, em seu art.93, institui a famosa "cota de deficientes" ao obrigar que as empresas privadas contratem pessoas com deficiência em um determinado percentual de sua força de trabalho. Antes da lei, temos alguns exemplos na própria Constituição de 1988 de políticas públicas e sociais de inclusão dessas pessoas. No art.37, VIII temos a previsão de reserva de vagas em cargos e empregos públicos. Nesse ponto específico podemos citar a lei estadual no 2.842/95 que determina que 5\% (cinco por cento) das vagas dos concursos público estaduais no Rio de Janeiro devem ser reservadas a pessoas com deficiência. Ainda na Constituição podemos citar o art.203, IV que prevê a concessão de benefício ao portador de deficiência que comprovar que não pode prover sua própria subsistência, o art.208, III que prevê o atendimento educacional a pessoas com deficiência, o art.227, § 1ํ, II que prevê a criação de programas de atendimento especial a

\footnotetext{
${ }^{6}$ GOMES, Joaquim Barbosa. Ação afirmativa e princípio constitucional da igualdade. Rio de Janeiro: Renovar, 2001. P. 3-4.

${ }^{7}$ SILVA, Alexandre Vitorino. Direitos a prestações positivas e igualdade: a deficiência São Paulo: LTr, 2007. P. 28.
} 
crianças com deficiência e o treinamento de adolescentes para o mercado de trabalho e o art.227, $\S 20$ c/c 244 que tratam da acessibilidade de espaços públicos incluindo edifícios públicos e veículos de transporte coletivo. 


\title{
CAPÍTULO II -AÇÕES AFIRMATIVAS E DISCRIMINAÇÕES LÍCITAS
}

As políticas de ação afirmativa originaram-se da necessidade de o Estado levar em consideração fatores que histórica e culturalmente foram determinantes na exclusão de um determinado grupo social, criando meios de prover o acesso desses grupos ao mercado de trabalho e também à instituições de ensino. Com o intuito de amenizar essa exclusão, o Estado cria obrigações e incentivos para que as entidades públicas ou privadas possam de alguma forma absorver aqueles naturalmente marginalizados para que as instituições reflitam minimamente a pluralidade que verificamos na sociedade como um todo.

As políticas afirmativas guardam íntima relação com o direito à igualdade mencionado supra. A superação do Estado Liberal clássico transformou o conceito tradicional de igualdade, ultrapassando o conceito de igualdade formal para o conceito de igualdade material. O Estado não mais pode se dar ao luxo de ficar neutro e apenas garantir aquela igualdade formal, prevista na lei mas que na prática tem sua efetivação dificultada por razões históricas e culturais. A inclusão do preceito constitucional da igualdade, portanto, não basta para que os direitos fundamentais sejam assegurados a todo cidadão, para que o preconceito seja erradicado e para que todos tenham garantida a igualdade de condições no acesso à educação, ao emprego e a participação política.

\begin{abstract}
"Por essa constatação histórica irrefutável é que, desde a década de 60 especialmente, começou a se fazer patente aos que tinham olhos com que ver claro, que o Direito Constitucional acanhava-se em sua concepção meramente formal do princípio denominado da isonomia, despojado de instrumentos de promoção da igualdade jurídica como vinha sendo até então cuidado. Conclui-se, então, que proibir a discriminação não era bastante para se ter a efetividade do princípio da igualdade jurídica. $O$ que naquele modelo se tinha e se tem é tãosomente o princípio da vedação da desigualdade, ou da invalidade do comportamento motivado por preconceito manifesto ou comprovado (ou comprovável), o que não pode ser considerado o mesmo que garantir a igualdade jurídica." ${ }^{8}$
\end{abstract}

Assim, consolidou-se a ideia de que a igualdade permitia e determinava o tratamento desigual de pessoas desiguais, sendo dever do Estado equiparar essas pessoas através de medidas de discriminação positiva, também conhecidas como ações afirmativas.

Historicamente, temos que já em 1968 o Brasil ratificou a Convenção 111 da OIT que em seu art.5o já reconhecia as peculiaridades de determinados grupos e legitimava o tratamento diferenciado:

\footnotetext{
${ }^{8}$ ROCHA, Carmen Lúcia Antunes. Ação afirmativa - o conteúdo democrático do princípio da igualdade jurídica. Revista Trimestral de Direito Público, São Paulo, n. 15, p.85-99, 1996.
} 
"Todo o Estado Membro pode, depois de consultadas as organizações representativas de patrões e trabalhadores, quando estas existam, definir como não discriminatórias quaisquer outras medidas especiais que tenham por fim salvaguardar as necessidades particulares de pessoas em relação às quais a atribuição de uma proteção e assistência especial seja, de uma maneira geral, reconhecida como necessária, por razões tais como o sexo, a invalidez, os encargos da família ou o nível social ou cultural."

Na mesma direção, temos a já citada Convenção 159 da OIT, promulgada pelo Decreto 129/91:

"4 - Essa política deverá ter como base o princípio de igualdade de oportunidades entre os
trabalhadores deficientes e dos trabalhadores em geral. Dever-se-á respeitar a igualdade de
oportunidades e de tratamento para os trabalhadores deficientes. As medidas positivas
especiais com a finalidade de atingir a igualdade efetiva de oportunidades e de tratamento
entre os trabalhadores deficientes e os demais trabalhadores, não devem ser vistas como
discriminatórias em relação a estes últimos."

A Constituição de 1988 traz algumas medidas de discriminação positiva, além de prover recursos para que o legislador institua ações afirmativas no âmbito infraconstitucional, como é o próprio caso da reserva de vagas e cargos em empregos públicos a portadores de deficiência disciplinada pela lei 8.112/90. Previu ainda a Constituição "proteção do mercado de trabalho da mulher, mediante incentivos específicos" (art. 7ㅇ, XX), além de expressamente proibir a discriminação no ambiente de trabalho em decorrência de cor, sexo, idade ou estado civil (XXX e XXXI), especial tratamento para a criança e para o adolescente e para os portadores de deficiência (art. 227) e aos índios (art. 231).

É, portanto, no contexto de tentativa de equiparação de toda a sociedade que se encaixa a o art.93 da lei 8.213/91 e tantos outros dispositivos legais aqui citados, inclusive os constitucionais. É o Estado se manifestando através de leis que visam equilibrar relações historicamente desequilibradas e excludentes. As ações afirmativas, nesse sentido, são quase sempre diretamente associadas às políticas de cotas, desde cotas para pessoas com deficiência até as polêmicas cotas para negros e índios. Porém, ações afirmativas não se limitam a cotas mas também se manifestam através de outras ações como incentivos fiscais a empresas que mantenham em seus quadros determinada parcela de grupos sociais minoritários ou ainda incentivos a empresas que adotem práticas como a promoção da educação de jovens. No entanto, no Brasil, o legislador tem focado as ações afirmativas apenas na questão das cotas, o que, em grande medida, se torna uma transferência de responsabilidade do Estado para a iniciativa privada, como veremos adiante. 
De acordo com Silva (2007) ação afirmativa e cotas não são sinônimos. Na verdade temos que as cotas são espécie do gênero ação afirmativa, aonde se inserem "outras medidas de promoção capazes de desempenhar o papel de instrumento de realização do princípio da igualdade material, tais como incentivos fiscais, educação especial de determinado grupo de pessoas e proteção ao mercado de trabalho dos grupos discriminados". ${ }^{9}$

Medidas da natureza das ações afirmativas são medidas naturalmente polêmicas e que geram resistência na sociedade. São medidas que modificam uma ordem consolidada tocando em interesses políticos, privilégios consagrados e interesses econômicos mas que nem por isso não devem ser adotadas. São um instrumento de grande valor para a consolidação da democracia e para valorização da diversidade em todas as esferas da sociedade. São instrumentos que pretendem reconhecer as desigualdades existentes e conferir tratamento diferenciado aos desiguais para que estes possam se equiparar a todos os demais.

"[Discriminação positiva ou ação afirmativa] consiste em dar tratamento preferencial a um grupo historicamente discriminado [...] impedindo assim que o princípio da igualdade formal, expresso em leis neutras que não levam em consideração os fatores de natureza cultural e histórica, funcione como perpetuador da desigualdade. Em suma, consiste em dar tratamento preferencial, favorável, àqueles que historicamente foram marginalizados, de sorte a colocá-los em um nível de competição similar ao daqueles que historicamente se beneficiaram da exclusão. Essa modalidade de discriminação, de caráter redistributivo e restaurador, destinada a corrigir uma situação de desigualdade historicamente comprovada, em geral, se justifica pela sua natureza temporária e pelos objetivos sociais que se visa com ela a atingir.." ${ }^{10}$

Além das ações e políticas afirmativas existem ainda as chamadas discriminações inevitáveis, admitidas pelo Direito. São inevitáveis por exemplo exclusões baseadas em critérios pessoais completamente incompatíveis com o desempenho de uma determinada função ou emprego. O próprio STF possui entendimento nesse sentido, objeto inclusive de Súmula, in verbis:

\footnotetext{
"Súmula 683 - O limite de idade para inscrição em concurso público só se legitima em face do art.70, XXX, da Constituição, quando possa ser justificado pela natureza das atribuições do cargo a ser preenchido"
}

O entendimento também encontra guarida na mais respeitável doutrina:

\footnotetext{
${ }^{9}$ SILVA, Alexandre Vitorino. Direitos a prestações positivas e igualdade: a deficiência São Paulo: LTr, 2007. P. 56

${ }^{10}$ GOMES, Joaquim Barbosa. Ação afirmativa e princípio constitucional da igualdade. Rio de Janeiro: Renovar, 2001. P. 22.
} 
“Em algumas situações especiais, porém, o tratamento discriminatório é chancelado pelo Direito. São situações em que a discriminação se reveste de inevitabilidade, seja em razão das exigências especiais do tipo de atividade, que exclui por princípio e com boa dose de razoabilidade certas categorias de pessoas, seja em função de características pessoais das pessoas envolvidas. (...) O Direito brasileiro, por exemplo, admite a exclusão de mulheres (ou de homens) de certas atividades, em razão da própria natureza da atividade a ser exercida. Assim, são legalmente admissíveis exigências tais como a de sexo feminino para candidatura a cargos de guardas de presídio feminino."11

Ainda no mesmo sentido, a Convenção 111 da OIT no seu art.1ำ dispõe que "distinções, exclusões ou preferências fundadas em qualificações exigidas para determinado emprego não são consideradas como discriminação". Dessa forma, exames psicológicos para ingressar em carreira como policial ou condutor de veículo de transporte urbano não são requisitos absurdos tendo em vista que para se portar uma arma ou para possuir a carteira nacional de habilitação que autoriza conduzir veículos de transporte de passageiros é razoável que se exija que o candidato possua equilíbrio emocional face às situações de estresse que as profissões em comento têm de enfrentar.

Da mesma forma temos que não seria discriminação restringir a admissão ao cargo de motorista a uma pessoa que não possua uma perna ou ainda ao cargo de telefonista a uma pessoa surda. Como tais limitações não podem ser superadas pelos meios tecnológicos disponíveis não é fora de propósito admitir a discriminação comentada como lícita.

A chave para se aferir a licitude da discriminação está no controle minucioso do caso concreto e não no fator que provoca a desigualdade. Deve-se observar se existe uma justificativa racional para se adotar um critério como fato discriminatório.

\section{II.I - O Princípio da Proporcionalidade}

O Princípio da proporcionalidade não está previsto em norma constitucional e seus fundamentos são apreendidos de forma diversa pela doutrina. Algumas vozes sustentam que a base do princípio reside nos próprios direitos fundamentais. Outros defendem que o dito princípio configura expressão do Estado Democrático de Direito tendo em vista o seu desenvolvimento histórico. Ou sustentam, ainda, tratar-se de um postulado jurídico com raízes no direito não positivado.

\footnotetext{
${ }^{11}$ GOMES, Joaquim Barbosa. Ação afirmativa e princípio constitucional da igualdade. Rio de Janeiro: Renovar, 2001. P. 21-22.
} 
O princípio da proporcionalidade foi concebido na doutrina alemã sendo denominado como o princípio da proibição ao excesso. Segundo o postulado, qualquer limitação aos direitos fundamentais deve passar pelo crivo desse princípio para ser considerada constitucional.

No Brasil a primeira referência de algum significado ao princípio da proporcionalidade na jurisprudência do Supremo Tribunal Federal ocorreu em sede de Recurso Extraordinário no ano de 1953, da relatoria do já falecido ministro Orozimbo Nonato, que deixou assente:

"O poder de taxar não pode chegar a desmedida do poder de destruir, uma vez que aquele somente pode ser exercido dentro dos limites que o tornem compatível com a liberdade do trabalho, de comércio e da indústria e com o direito de propriedade. É um poder, cujo exercício não deve ir até o abuso, o excesso, o desvio, sendo aplicável, ainda aqui a doutrina fecunda do "détournement de pouvoir". Não há que estranhar a invocação dessa doutrina ao propósito da inconstitucionalidade, quando os julgados têm proclamado que o conflito entre a norma comum e o preceito da Lei Maior pode se acender não somente se considerando a letra do texto, como também, e principalmente, o espírito do dispositivo invocado."12

Nota-se que já em 1953 apontava-se para a doutrina do "excesso de poder" para o controle da atividade legislativa. E embora a questão em apreço restrinja-se ao direito de propriedade, parece certo que o juízo desenvolvido se mostra aplicável em relação a qualquer providência legislativa destinada a restringir direitos.

Ao longo dos anos e mais recentemente já sob a égide da Constituição de 1988, a jurisprudência brasileira consolidou o entendimento de que o princípio é um postulado constitucional autônomo que teria sua sede material na disposição constitucional sobre o devido processo legal (art.5o, LIV). ${ }^{13}$ Assenta-se, assim, como princípio geral do Direito.

Sobre o assunto, a doutrina identifica como típica manifestação do excesso de poder legislativo a violação do princípio da proporcionalidade ou da proibição do excesso, que se revela mediante contraditoriedade, incongruência e irrazoabilidade ou inadequação entre meios e fins. Nesse diapasão, Bonavides enumera três subprincípios componentes do princípio da proporcionalidade: adequação, necessidade e proporcionalidade em sentido estrito. ${ }^{14}$

O primeiro relaciona-se com a verificação de se o meio escolhido é o meio certo para se alcançar o objetivo pretendido. Se o fim almejado somente poderá ser alcançado por uma medida restritiva tal medida então é necessária. Porém, o subprincípio da necessidade impõe

\footnotetext{
${ }^{12}$ RE 18.331, Rel. Orozimbo Nonato, RF, 145/164, 1953.

${ }^{13}$ MENDES, Gilmar. Curso de Direito Constitucional. 2ª ed. São Paulo: Saraiva, 2008. P.327-328.

${ }^{14}$ SILVA, Alexandre Vitorino. Direitos a prestações positivas e igualdade: a deficiência São Paulo: LTr, 2007. P. 44.
} 
que "dentre todas as medidas possíveis, seja escolhida a que cause menor dano às liberdades públicas e menor sacrifício aos titulares de direitos. Cuida-se de preservar o máximo de liberdade e de evitar intervenções ilegítimas do Estado na esfera subjetiva de cada pessoa"

Já a proporcionalidade em sentido estrito de Bonavides é na realidade a razoabilidade que determina uma comparação de peso entre a restrição imposta a um direito fundamental e o benefício comum ou interesse público pretendido. Se o benefício comum for preponderante e compensar a limitação individual sofrida, então temos que a medida é razoável.

Com relação a questões trabalhistas e restrições impostas, o Supremo já teve que lidar com diversas situações em que fez uso do princípio da proporcionalidade como instrumento essencial para julgar o mérito. A Corte, por exemplo, já julgou razoável a exigência de estatura mínima para exercer o cargo de delegado, pois mitigou o direito ao trabalho pelo motivo questionável da necessidade de porte intimidador para o exercício da função (Informativo 191 STF).

Em um caso mais interessante, o Supremo Tribunal Federal já decidiu que deficientes visuais não podem exercer a magistratura. Entendeu a Corte Constitucional que para o desempenho da função de juiz é necessário uma série de atividades como a leitura de textos legais, provas escritas nos autos (inclusive fotografias, gráficos) e a observação da reação facial das testemunhas e das partes nas audiências que devem ser realizadas pelo próprio juiz de forma imparcial, em atenção, inclusive, ao princípio da pessoalidade da apreciação da prova.

\begin{abstract}
"ADMISSAO AO CARGO DE JUIZ DE DIREITO. CEGUEIRA BILATERAL TOTAL. INCAPACIDADE FÍSICA PARA ESSA ADMISSAO. - INEXISTÊNCIA DE OFENSA AO INCISO III DO ARTIGO ÚNICO DA EMENDA CONSTITUCIONAL N. 12/78, UMA VEZ QUE A DECISÃO QUE ENTENDE QUE A CEGUEIRA BILATERAL TOTAL IMPOSSIBILITA O DESEMPENHO PLENO DAS ATRIBUIÇÕES INSITAS AO CARGO DE JUIZ DE DIREITO NÃO E DISCRIMINATORIA. - A LEI COMPLEMENTAR N. 35/79, EM SEU ARTIGO 78, PARAGRAFO 2., ESTABELECE QUE OS CANDIDATOS A JUIZ SERÃO SUBMETIDOS A EXAME DE SANIDADE FÍSICA, CONFORME DISPUSER A LEI; E A LEI 6750/79, POSTERIOR AQUELA, INCLUIU ENTRE OS REQUISITOS DE INGRESSO NA CARREIRA DA MAGISTRATURA DO DISTRITO FEDERAL E DOS TERRITORIOS O DE O CANDIDATO 'SER MORALMENTE IDONEO E GOZAR DE SANIDADE FÍSICA E MENTAL' (INCISO VI DO ARTIGO 46). NÃO-OCORRENCIA, POIS, DE VIOLAÇÃO DO PARAGRAFO 2. DO ARTIGO 153, DO CAPUT DO ARTIGO 97 E DO INCISO I DO ARTIGO 144, TODOS DA CONSTITUIÇÃO FEDERAL. - AOS MEDICOS CABE DETERMINAR A EXISTÊNCIA E A EXTENSAO DA DEFICIÊNCIA FÍSICA; AO TRIBUNAL, POREM, E QUE COMPETE AFERIR SE ELA PERMITE, OU NÃO, O DESEMPENHO PLENO E NORMAL DAS FUNÇÕES DO CARGO DE JUIZ. RECURSO EXTRAORDINÁRIO NÃO CONHECIDO" ${ }^{15}$
\end{abstract}

\footnotetext{
${ }^{15}$ RE 100001-5/DF. Relator Moreira Alves, STF. Julgamento em 29/3/84.
} 
Podemos depreender que, assim, é admissível que não se empregue pessoas com deficiência em determinadas funções a depender do tipo de atividade que a pessoa terá que desempenhar.

Para o Direito norte-americano, a título de comparação, faz sentido não empregar pessoas com deficiência se o empregador provar que o exercício de uma determinada função por um portador de uma determinada deficiência ameaça a saúde ou a segurança de outros indivíduos. É exatamente isso que prevê uma lei federal conhecida como ADA (Americans with Disabilities Act).

Tendo isso em vista, cabe questionar se as limitações ao direito fundamental de acesso livre ao trabalho para serem entendidas como lícitas e necessárias exigiriam a existência de um risco significante. Não parece ser esse o entendimento no Brasil, tendo em vista as decisões judiciais sobre o assunto que apenas levam em considerações as possibilidades da pessoa com deficiência e as atividades exigidas para o exercício da função. 


\section{CAPÍTULO III - A COTA DO ART. 93 DA LEI № 8.213/91}

Toda empresa privada com mais de 100 empregados está sujeita ao art.93 da Lei no 8.213/91 que determina cotas compulsórias para a admissão e demissão de pessoas portadoras de deficiência. A lei prevê que um determinado percentual do quadro funcional deve obrigatoriamente ser composto por pessoas portadoras de deficiência e que a dispensa de um desses trabalhadores só pode ocorrer após ser feita a contratação de outro em condição semelhante.

Art. 93. A empresa com 100 (cem) ou mais empregados está obrigada a preencher de $2 \%$ (dois por cento) a $5 \%$ (cinco por cento) dos seus cargos com beneficiários reabilitados ou pessoas portadoras de deficiência, habilitadas, na seguinte proporção:

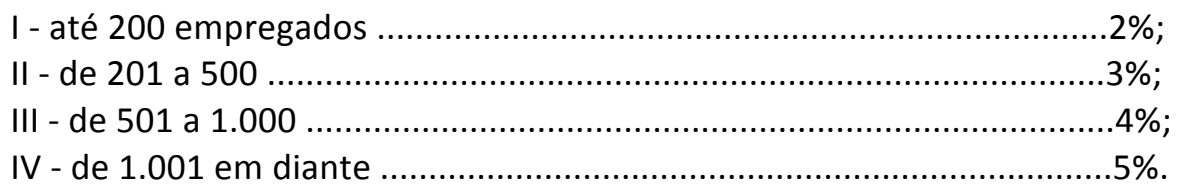

$\S 10$ A dispensa de trabalhador reabilitado ou de deficiente habilitado ao final de contrato por prazo determinado de mais de 90 (noventa) dias, e a imotivada, no contrato por prazo indeterminado, só poderá ocorrer após a contratação de substituto de condição semelhante.

$\S 2$ 2 O Ministério do Trabalho e da Previdência Social deverá gerar estatísticas sobre o total de empregados e as vagas preenchidas por reabilitados e deficientes habilitados, fornecendo-as, quando solicitadas, aos sindicatos ou entidades representativas dos empregados.

O Decreto no 3.298/99, no art. 36, além de consolidar a reserva de mercado, repetiu o conteúdo do primeiro parágrafo do art. 93 da Lei № 8.213, adicionou funções a serem exercidas pelo Ministério do Trabalho e Emprego e tratou sobre o conceito de pessoa com deficiência habilitada para os fins da lei, em três novos parágrafos.

Art. 36. A empresa com cem ou mais empregados está obrigada a preencher de dois a cinco por cento de seus cargos com beneficiários da Previdência Social reabilitados ou com pessoa portadora de deficiência habilitada, na seguinte proporção:

I - até duzentos empregados, dois por cento;

II - de duzentos e um a quinhentos empregados, três por cento;

III - de quinhentos e um a mil empregados, quatro por cento; ou

IV - mais de mil empregados, cinco por cento.

$\S 1^{\circ} \mathrm{A}$ dispensa de empregado na condição estabelecida neste artigo, quando se tratar de contrato por prazo determinado, superior a noventa dias, e a dispensa imotivada, no contrato por prazo indeterminado, somente poderá ocorrer após a contratação de substituto em condições semelhantes.

$\S 2^{\circ}$ Considera-se pessoa portadora de deficiência habilitada aquela que concluiu curso de educação profissional de nível básico, técnico ou tecnológico, ou curso superior, com certificação ou diplomação expedida por instituição pública ou privada, legalmente credenciada pelo Ministério da Educação ou órgão equivalente, ou aquela com certificado de conclusão de processo de habilitação ou reabilitação profissional fornecido pelo Instituto Nacional do Seguro Social - INSS. 
$\S 3^{\circ}$ Considera-se, também, pessoa portadora de deficiência habilitada aquela que, não tendo se submetido a processo de habilitação ou reabilitação, esteja capacitada para o exercício da função.

$\S 4^{\circ} \mathrm{A}$ pessoa portadora de deficiência habilitada nos termos dos $\S \S 2^{\circ}$ e $3^{\circ}$ deste artigo poderá recorrer à intermediação de órgão integrante do sistema público de emprego, para fins de inclusão laboral na forma deste artigo.

$\S 5^{\circ}$ Compete ao Ministério do Trabalho e Emprego estabelecer sistemática de fiscalização, avaliação e controle das empresas, bem como instituir procedimentos e formulários que propiciem estatísticas sobre o número de empregados portadores de deficiência e de vagas preenchidas, para fins de acompanhamento do disposto no caput deste artigo.

Pela lei, é preciso que o trabalhador com deficiência seja habilitado, o que está definido nos $\S \S 2$ e 3 do art.36 do Decreto no 3.298/99, transcrito supra. O legislador, reconheça-se, buscou adotar um sentido amplo de habilitação com o intuito de incluir o máximo possível de portadores de deficiência no critério da lei, pois, mesmo aqueles que não tenham concluído curso técnico ou profissional algum, poderão ser considerados habilitados caso estejam capacitados para o exercício de determinada função.

Com relação aos percentuais contidos na lei, estes relacionam-se com o número de empregados total que a empresa possui. Naquelas empresas que possuem mais de um estabelecimento, com CNPJ diferentes, o cálculo da reserva de vagas recai sobre o total de empregados, somados todos os empregados de todos os estabelecimentos, segundo o entendimento dominante da doutrina já que a lei fala em empresa e não em estabelecimento.

Quando o cálculo do percentual, por sua vez, resulta em um número fracionado, elevase a fração arredondando-se para cima até o primeiro número inteiro. É este o entendimento do Supremo:

"De ter-se, em face da obrigatoriedade da reserva de vagas para portadores de deficiências, que a fração, a exemplo do disposto no Decreto n. 3.298/99, seja elevada ao primeiro número inteiro subseqüente, no caso 01 (um), como medida necessária a emprestar-se eficácia ao texto constitucional, que, caso contrário, sofreria ofensa." ${ }^{16}$

No tocante à demissão do empregado a lei estabelece que para a dispensa ser legítima é necessário que a empresa contrate antes um substituto em condição semelhante. A regra é um mecanismo de preservação da reserva de vagas e caso o empregador dispense um empregado sem ter contratado outro em condição semelhante para o seu lugar, a dispensa terá sido nula, segundo dominante entendimento do TST.

\footnotetext{
${ }^{16}$ RE n. 227.299-1/MG. Relator: Min. Ilmar Galvão, Informativo n. 193.
} 
“ESTABILIDADE PROVISÓRIA. DESPEDIDA. VALIDADE. EMPREGADO REABILITADO. ART. 93, §o 1, DA LEI 8.213/91. 1. O art. 93, § 1으, da Lei 8.213/91, ao vedar a dispensa de empregado deficiente ou reabilitado antes da contratação de outro empregado em condição semelhante, não instituiu propriamente uma modalidade de garantia de emprego, mas um ato jurídico submetido a uma condição suspensiva: admissão de empregado -de condição semelhante-. 2. A inobservância da lei, ante a ausência de prova do implemento da condição, acarreta a nulidade da despedida, seja em face da lei civil (CC de 2002, art. 125), seja em face da CLT (art. 9o), mormente porque frustra o patente escopo protetivo da lei. 3. Exegese que se revela mais consentânea com o postulado constitucional da não-discriminação do trabalhador portador de deficiência (art. 7ㅇ, XXXI, da CF). Ademais, a proteção conferida a tais empregados, em razão da fragilidade da situação em que se encontram, beneficia antes a coletividade que a si mesmos. 4 . Não se sustenta a diretriz segundo a qual, em semelhante situação, caberia tão-somente impor sanção de natureza administrativa ao empregador. A prevalecer tal orientação, frustar-se-iam os desígnios do legislador. Patente que resultaria vã a proteção que se quis oferecer aos empregados deficientes e reabilitados, malogrando-se o escopo da lei e esvaziando-lhe o seu próprio sentido, pois decerto conviria mais ao empregador suportar o ônus financeiro da multa. 5. Recurso de revista de que se conhece e a que se dá provimento para determinar a reintegração do Reclamante e sua manutenção no emprego até que o Reclamado promova a contratação de substituto de condição semelhante." . ${ }^{17}$

Porém, na prática encontramos problemas que dificultam o cumprimento dessa norma.

Encontramos na realidade do mercado ausência de políticas públicas de habilitação profissional o que resulta em escassez de profissionais habilitados. A consequência é que o Ministério Público do Trabalho tem firmado termos de ajustamento de conduta com as empresas, flexibilizando a regra do cumprimento imediato da cota.

A fiscalização do cumprimento da cota prevista no art.93 cabe ao Ministério do Trabalho e Emprego, conforme $\S 5$ o do art.36 do Decreto n $3.298 / 99$ supra transcrito. Os auditores fiscais do trabalho fiscalizam as empresas de forma aleatória e verificam a existência de vínculo empregatício e o cumprimento ou não da reserva de vagas. Quando é verificada alguma irregularidade o auditor encaminha a informação para instauração de procedimento administrativo que normalmente resulta em um Termo de Compromisso firmado com a Superintendência Regional do Trabalho e/ou multa. Se o Termo não for cumprido, informa-se ao Ministério Público do Trabalho. A partir daí, o MPT tem tentado firmar Termos de Ajustamento de Conduta que quando não surtem o efeito esperado resultam em ações civis públicas que objetivam condenar o réu a contratar as pessoas portadoras de deficiência e eventualmente ao pagamento de indenizações punitivas pelos danos causados à sociedade.

\footnotetext{
${ }^{17}$ RR - 199/2002-008-17-00.4. Relator Min. João Oreste Dalazen, $1^{\text {a }}$ Turma. Publicado no DJ de 9/7/2004. No mesmo sentido, o acórdão TST-RR-646.255/2000.2, Ac. $3^{\text {a }}$ Turma, Rel. Min. Carlos Alberto Reis de Paula, julgado em 12/3/2003, DJ de 4/4/2003.
} 
III. I - A cota do art.93 da lei no 8.213/91 e a empregabilidade da pessoa com deficiência

Apesar do inegável avanço promovido pela famosa "lei das cotas", a participação de pessoas com deficiência no mercado de trabalho formal ainda é muito baixa. Segundo dados do Ministério do Trabalho e Emprego (MTE) obtidos através da Relação Anual de Informações Sociais (Rais) em 2007, o número de pessoas com deficiência contratadas formalmente era de 350 mil pessoas; em 2008, 320 mil; em 2009 esse índice cai para 290 mil e em 2010 pouco oscilou para exatas 292.614 pessoas com deficiência formalmente contratadas (até dezembro de 2010). Houve, portanto, no acumulado de 2010 um saldo positivo de 4.021 vagas de emprego em relação ao estoque de vagas acumulado de 2009.

Com relação ao tipo de deficiência, do saldo de 4.021 vagas apresentado em 2010, temos o seguinte panorama:

Tabela 1

\begin{tabular}{|c|c|c|c|c|c|c|}
\hline \multicolumn{7}{|c|}{ SALDO DE EMPREGOS POR TIPO DE DEFICIÊNCIA - 2010 } \\
\hline Física & Auditiva & Visual & Mental & Múltipla & Reabilitados & TOTAL \\
\hline 2866 & 335 & 1314 & 1850 & 70 & -2414 & $\mathbf{4 0 2 1}$ \\
\hline
\end{tabular}

No total do ano foram 73.274 contratações de deficientes, sendo 54,8\% (40.712) deficientes físicos. As demissões somaram 69.253, sendo a diferença o saldo de 4021.

Com relação aos setores que mais vagas criaram para os portadores de deficiência:

Tabela 2

\begin{tabular}{|c|c|c|c|}
\hline \multicolumn{4}{|c|}{ DESTAQUES SETORIAIS - 2010 } \\
\hline Serviços & Comércio & Indústria & Administração Pública \\
\hline 2590 & 1714 & 537 & 339 \\
\hline
\end{tabular}

Destaque negativo para a Administração Pública que teve o menor saldo positivo de vagas criadas para portadores de deficiência, quando se espera justamente o contrário. Todos os outros setores apresentaram demissões maiores do que admissões e, portanto, saldo negativo. O setor que mais demitiu foi o de Agropecuária, extração vegetal, caça e pesca (529 vagas), seguido pelo de Construção Civil (-370) e Serviços industriais de utilidade pública $(-327)$. 
Com relação ao saldo de empregos por gêneros temos um panorama instigante:

Tabela 3

SALDO DE EMPREGOS POR GÊNERO - 2010

\begin{tabular}{|c|c|c|}
\hline Masculino & Feminino & TOTAL \\
\hline 131 & 3890 & $\mathbf{4 0 2 1}$ \\
\hline
\end{tabular}

Nota-se uma discrepância enorme a favor do sexo feminino. Das 4021 vagas criadas, $96,7 \%$ corresponderam ao emprego feminino e apenas 3,3\% ao masculino. O Ministério do Trabalho não explica o motivo dessa discrepância.

Não menos interessante a análise dos empregos criados por faixa salarial:

Tabela 4

\begin{tabular}{|l|c|}
\hline \multicolumn{2}{|c|}{ SALDO DE EMPREGOS POR FAIXA SALARIAL - 2010 } \\
\hline Até 0,5 Salários Mínimos & 455 \\
\hline De 0,5 a 1,0 & 3584 \\
\hline De 1,01 a 1,5 & 3443 \\
\hline De 1,51 a 10,0 & -3454 \\
\hline De 10,01 a 15,0 & -28 \\
\hline De 15,01 a 20,0 & 6 \\
\hline Mais de 20,0 & -31 \\
\hline Ignorado & 46 \\
\hline TOTAL & $\mathbf{4 0 2 1}$ \\
\hline
\end{tabular}

Apesar da elevação do saldo de emprego, verifica-se que o acréscimo de vagas ocorreu nos empregos de menor remuneração, até 1,5 salários mínimos. A redução de postos de trabalho para deficientes que ganham entre 1,51 e 10 salários mínimos foi significativa, apresentando uma redução de 3.454 empregos. A criação de vagas ocorreu, portanto, em empregos que exigem, em geral, pouca qualificação.

Esses indicadores apontam que muitas pessoas com deficiência continuam exercendo atividades informais, precárias e muito provavelmente sem continuidade ou simplesmente não possuem ocupação alguma. Os indicadores do Ministério do Trabalho também deixam claro que, embora importante, a "lei de cotas" não cumpre inteiramente o seu papel visto que se fosse totalmente cumprida estima-se que 800 mil vagas de emprego estariam ocupadas por 
pessoas com alguma deficiência. E mesmo sendo cumprida na íntegra, a lei ainda deixaria de fora milhões de brasileiros portadores de necessidades especiais.

Não se discute aqui a importância de medidas afirmativas. Elas são necessárias e, como visto, contribuem para o efetivo respeito ao princípio da igualdade constitucional. No entanto, como podemos notar pelos dados do mercado de trabalho, a medida afirmativa que o Brasil dispõe hoje para as pessoas com deficiência não se mostra adequada. A lei é vista pela maioria das empresas como uma crise, um fardo e não como oportunidade para, por exemplo, promover a diversidade no âmbito empresarial.

Muitos estudos mostram que promover a diversidade no mercado de trabalho trás muitos benefícios para as empresas. Pessoas com formações diferentes, visões diferentes, idades, orientações políticas diferentes, reunidas todas em um mesmo ambiente tendem a proporcionar uma visão mais holística e contribuir para a criatividade, inovação e para a tão almejada melhoria contínua nas empresas. A lei deveria incentivar uma política de inclusão que criasse um grupo heterogêneo aonde a troca de experiências e opiniões enriquece o ambiente de trabalho. As empresas deveriam ser incentivadas a adotar estratégias de cultivo da diversidade com o objetivo de ampliar a visão global da organização e contribuir para sua integração à sociedade.

No entanto, a lei no $8.213 / 91$ não contribui para tanto. A lei simplesmente prevê a reserva de vagas, como se isso fosse o bastante para resolver um problema tão complexo como a inclusão de pessoas portadoras de deficiência no mercado de trabalho. O próximo capítulo, portanto, apontará as falhas e lacunas da lei que ajudam a explicar o porque ser tão difícil efetivar uma medida afirmativa tão nobre. 


\section{CAPÍTULO IV - ANÁLISE CRÍTICA DO ART.93 DA LEI № 8.213/91: AS DIFICULDADES DE EFETIVAÇÃO DA LEI}

\section{IV.I - A não diferenciação das empresas por ramo de atividade}

Quando analisados os dados da realidade do mercado de trabalho e mais especificamente os dados de empregabilidade das pessoas com deficiência podemos perceber que a lei não basta para atingir os fins a que se pretende. A lei simplesmente prevê percentuais que as empresas devem cumprir, porém não tem o cuidado de especificar a área de atuação da empresa, o segmento empresarial.

$\mathrm{Na}$ realidade do mercado temos que algumas empresas, devido ao seu ramo de atuação, tem mais dificuldade do que outras para cumprir a cota do art.93 da lei no 8.213/91. Por razões de ordem prática, são empresas que atuam em segmentos que exigem uma qualificação específica de mão-de-obra. Essas empresas exercem atividades que demandam trabalhadores com uma certa qualificação, o que muitas vezes inviabiliza ou torna extremamente difícil o cumprimento da lei.

Tomemos o exemplo de uma empresa que presta serviços de vigilância noturna. As exigências para a grande maioria da força de trabalho dessa empresa, os vigilantes, são altas tendo em vista o tipo de atividade a ser desenvolvida. Visão adequada, condições psicológicas e condicionamento físico não são exigências absurdas ou descabidas para a seleção do quadro de pessoal de uma empresa como essa. Tais exigências encontram justificativa racional e não podem ser consideradas como discriminação ilícita. Além disso, por exigência legal (Lei no. 7.102 de 20 de junho de 1983) os seguranças e vigilantes são obrigados a participar de cursos em academias credenciadas pelo Departamento da Polícia Federal e só podem exercer o ofício mediante aprovação nesses cursos.

Apesar disso, os Tribunais ainda não se posicionaram firmemente sobre a questão. Há decisões que defendem a flexibilização da norma e outras que entendem que a lei deve ser cumprida independente do ramo de atividade ou da atividade preponderante da empresa visto que sempre seria possível encontrar pessoas com algum tipo de deficiência que não impossibilite-a de exercer a função. Essa segunda visão nos parece uma interpretação extremamente isolada, literal e pouco produtiva. Se é notório que todas as empresas tem dificuldade de encontrar profissionais habilitados para preencher a reserva de vagas prevista em lei, que dirá empresas que tem em seu quadro funcional majoritariamente trabalhadores que necessitam, as vezes por imposição legal, de algum tipo de capacitação ou requisito 
mínimo obrigatório. Porém, não tem sido esse o entendimento de alguns Tribunais, mormente o Tribunal Superior do Trabalho, que já decidiu pela aplicação literal da norma no caso de empresas de vigilância:

"A ré requer a exclusão dos vigilantes da base de cálculo das vagas, pois o desempenho de suas atividades de proteção patrimonial exigiria pessoas totalmente aptas, física e psicologicamente. O inconformismo não merece prosperar.

Embora a premissa esteja correta, no sentido de que os serviços de vigilância devam ser exercidos por trabalhadores aptos, física e mentalmente, conforme a Lei no 7.102/83, há de se ponderar que há tipos de limitação física que não impedem a aptidão plena, circunstância a qual deve ser aferida por médico e psicólogo, responsáveis pelos exames físico, mental e psicotécnico.

(...)

Embora, em princípio, possa causar estranheza a empregabilidade do deficiente físico no serviço de vigilância, é imperioso excluir o preconceito do raciocínio lógico para concluir que deficiências menores, tais como perda de um dedo (como relatado à fl. 54) ou quiçá, encurtamento de um membro inferior, sem prejuízo de outros, não impedem que o trabalhador mantenha a higidez imprescindível para efeito da prestação de serviços oferecida pela ré.

(...)

Com efeito, conforme relata a Corte Regional, prova documental comprovou que é possível que pessoa portadora de deficiência física participe de cursos de formação de vigilantes, e que determinadas deficiências não impedem o exercício da função de vigilante, de forma que não há falar na exclusão destes da base de cálculo dos percentuais referidos na Lei no 8.213/91." ${ }^{18}$

Outro exemplo onde fica clara essa dificuldade são as empresas de transporte. As empresas de transporte, por óbvio, tem em seu quadro funcional a maior parte dos empregados exercendo a função de motorista. É uma função que exige requisitos mínimos obrigatórios, inclusive por imposição legal, sendo o mais notório a posse da Carteira Nacional de Habilitação. Para se ter esse documento, a própria lei impõe alguns exames obrigatórios entre eles um exame psicotécnico e alguns exames práticos. É claro que tais imposições justificam-se tendo em vista que o trânsito nas cidades e estradas necessita de um regramento mínimo e os motoristas, por sua vez, necessitam possuir habilidades mínimas para poderem conduzir veículos. São regras que visam a segurança e bem estar de toda a sociedade. E com muito mais razão, regras que devem ser seguidas por motoristas de veículos coletivos de transporte de passageiros e de cargas.

Ora, se o próprio Estado, através dos DETRAN's estaduais toma para si o monopólio de permitir ou não que as pessoas possam conduzir veículos e muitas vezes nega esse direito para pessoas com deficiência tendo em vista limitações físicas ou mentais, como poderia o Estado

\footnotetext{
${ }^{18}$ TST, RR-129600-12.2006.5.02.0090, Relatora Ministra Maria Cristina Irigoyen Peduzzi, Publicado em 03/09/2010
} 
obrigar uma empresa que tem em seu quadro funcional majoritariamente motoristas a contratar pessoas com deficiência? É um contra senso.

Não por acaso, a Comissão de Viação e Transportes da Câmara de Deputados já apresentou projetos de lei para facilitar, no âmbito do setor de transporte de cargas, o cumprimento da legislação que impõe às empresas cotas para empregar trabalhadores com deficiência e aprendizes. A tendência era propor a redução ou mesmo a não aplicação da cota a alguns setores específicos de atividade econômica. ${ }^{19}$ É certo que os projetos apresentados nunca foram a votação na Câmara, mas apenas a existência de propostas já denota que o legislador, de alguma forma, reconhece que se omitiu por demais na lei original.

Ainda nesse sentido, vale notar um interessante posicionamento do Judiciário mineiro quanto à questão da base de cálculo a ser considerada para a definição do número de jovens aprendizes a serem contratados por uma empresa de transportes por ônibus. A lei de aprendizagem, Lei no 10.097 de 19 de dezembro de 2000 que alterou alguns artigos da CLT, assim como a Lei no 8.213 em seu art.93, estabelece cotas para a contratação de jovens aprendizes conforme o número de empregados da empresa em funções que exijam qualificação profissional. Senão vejamos:

\footnotetext{
"Art. 429. Os estabelecimentos de qualquer natureza são obrigados a empregar e matricular nos cursos dos Serviços Nacionais de Aprendizagem número de aprendizes equivalente a cinco por cento, no mínimo, e quinze por cento, no máximo, dos trabalhadores existentes em cada estabelecimento, cujas funções demandem formação profissional." (grifo meu)
}

É certo que os fins da lei são outros, qual seja, o de inserir jovens com formação profissional mas sem experiência alguma no mercado de trabalho. Mas vale conferir decisão marcante do Tribunal Regional do Trabalho de Minas Gerais que em sede de Recurso Ordinário deu razão à uma empresa de ônibus para excluir da base de cálculo para a cota de aprendizes as funções de motorista e cobrador. Segundo o acórdão:

\footnotetext{
"Não se pode perder de vista que para se habilitar a motorista de transporte coletivo de passageiros, o Código Nacional de Trânsito exige, em seu artigo 145, que o candidato seja maior de 21 anos, esteja habilitado nas categorias B, C ou D, não tenha cometido infração de trânsito grave ou gravíssima ou ser reincidente em infrações médias, além de ter sido aprovado em curso especializado e curso de treinamento de prática veicular em situação de risco. Daí já se vê̂
}

\footnotetext{
19 Informativo da Câmara dos Deputados. Disponível em http://www2.camara.gov.br/agencia/ noticias/134253.html. Acesso em 15 out. 2011.
} 
que o primeiro dos requisitos se mostra incompatível com a contratação de "menores aprendizes" para esta função." 20

A decisão cita ainda outra acórdão no mesmo sentido:

“EMENTA: CONTRATO DE APRENDIZAGEM -NÚMERO MÍNIMO DE APRENDIZES - BASE DE CÁLCULO - MOTORISTA E COBRADOR DE ÔNIBUS URBANO. Embora as funções de motorista de ônibus urbano e de cobrador encontrem-se previstas na Classificação Brasileira de Ocupações (CBO), elaborada pelo Ministério do Trabalho e Emprego, devem ser ambas excluídas do número total de empregados para efeito de cálculo da cota de aprendizes que o empregador deverá admitir, por se tratar de atividades que exigem conhecimento técnico específico, manuseio de valores, além de oferecer acentuado risco em razão de múltiplos e conhecidos fatores que envolvem o trânsito nos centros urbanos". ${ }^{21}$

Ora, se a cota de aprendizagem pode ser flexibilizada não resta dúvidas que o mesmo pode ocorrer com a cota do art.93 da lei $\mathrm{n}$ - 8.213/91. A função de motorista exige conhecimento e habilidade técnica específica que muitas vezes inviabiliza a contratação de pessoas com deficiência por mais que a empresa se esforce nesse sentido. Os argumentos contrários sustentam, porém, que no caso dos portadores de deficiência, alguns podem ser capazes de desempenhar a função. Isso é uma verdade, reconheça-se, porém, o fato é que na prática as empresas não conseguem encontrar pessoas com deficiência habilitadas na proporção que a lei exige. Registre-se uma proporção igual para qualquer empresa, independente da atividade exercida.

Devido a essa dificuldade muitas empresas vêm obtendo êxito judicialmente na anulação de multas aplicadas pelo não cumprimento da cota em sede administrativa. Como noticiado no jornal Valor Econômico, no dia 25.10.2010:

“Em decisões recentes, os Tribunais Regionais do Trabalho (TRTs) de São Paulo, Rio de Janeiro e Brasília anularam multas sofridas pelas empresas, por entender que elas, apesar de não alcançarem os índices exigidos, empenharam-se no cumprimento da lei. Pela Lei no 8.213, as empresas com mais de cem empregados são obrigadas a destinar de $2 \%$ a $5 \%$ de suas vagas para deficientes. Uma empresa de transportes do Rio com 984 funcionários, por exemplo, viu-se obrigada a contratar 40 empregados deficientes - $4 \%$ do total de trabalhadores - para cumprir a norma. Mesmo abrindo concurso, só conseguiu 26 funcionários. Por não atingir a meta, foi autuada em 2003 em cerca de R\$ 200 mil, em valores atualizados. Na Justiça, a companhia conseguiu no início deste mês cancelar a multa. Da decisão, porém, cabe recurso. 0 juiz José Mateus Alexandre Romano, da 38a Vara do Trabalho do Rio, entendeu que a aplicação da lei

\footnotetext{
${ }^{20}$ TRT - 3a RE, 0001154-56.2010.5.03.0111 RO, Relator Juiz Convocado Dr. João Bosco Pinto Lara, Publ. $18 / 02 / 2011$

${ }^{21}$ TRT - 3a RE, 1403-2009-138-03-00-7-RO, Relator Des. Marcus Moura Ferreira, Publ. 16/07/10
} 
deve respeitar o princípio da razoabilidade. Segundo o magistrado, a companhia demonstrou que "as vagas existem, o que não existe é profissional qualificado no emprego". Para ele, "obrigar empresas a contratarem qualquer um, um despreparado, sem qualificação profissional, é o mesmo que colocar em risco o empreendimento".

Nesse sentido também já se manifestou a Comissão de Estudos para a Inclusão da Pessoa Portadora de Deficiência, através do ofício no 037/02 da Procuradoria Geral do Ministério Público do Trabalho, datado de 24 de maio de 2002:

\footnotetext{
"O elemento impeditivo seria a falta de capacitação e não a deficiência. Se determinada atividade contar com grande número de funções que por suas peculiaridades (condições agressivas, necessidade de aptidão plena, etc) dificultem a reserva legal no percentual exigido, deverá a empresa buscar o cumprimento da reserva nas vagas restantes, onde a falta de capacitação específica, atribuída ou não à deficiência, não seja elemento impeditivo do exercício da função. Se essas funções não forem em número suficiente tem-se a impossibilidade jurídica do cumprimento da lei."
}

Além da lei não diferenciar a empresa por ramo de atuação, também não o faz com relação à atividade a ser desenvolvida pelo empregado. Por esse motivo, muitas empresas acabam contratando todas as pessoas com deficiência apenas para uma função. É muito comum empresas de ramos como construção civil, metalurgia, siderurgia, transportes e outros contratar todas as pessoas com deficiência apenas para exercer uma função administrativa como por exemplo serviço de atendimento ao cliente. Ou ainda auxiliares administrativos. Esse assunto será mais exaustivamente abordado no ponto IV.V.

\section{IV.II - A falta de profissionais qualificados no mercado de trabalho}

O art.36, §3으 do Decreto № 3.298 dispõe que “Considera-se, também, pessoa portadora de deficiência habilitada aquela que, não tendo se submetido a processo de habilitação ou reabilitação, esteja capacitada para o exercício da função". Ou seja, se não há pessoas habilitadas as empresas podem tentar encontrar pessoas capacitadas no mercado para exercer determinada função. Aqui é que reside o problema.

A falta de capacitação profissional é um obstáculo encontrado pelas empresas no momento de contratar pessoas com deficiência. Na verdade em momento de crescimento econômico e expansão da atividade produtiva o problema da falta de pessoal qualificado é crônico de todo o mercado de trabalho e fica ainda mais agudo no caso dos portadores de deficiência. Existem muitas explicações para esse fato, sendo as mais aceitas o "histórico de exclusão, que dentro outros fatores, ocasionou um grande déficit educacional na população 
com deficiência" e as diversas dificuldades encontradas por essas pessoas no acesso a programas de habilitação que sejam condizentes com as exigências do mercado.

\begin{abstract}
"Ressalta-se, neste sentido, a inexistência de cursos profissionalizantes direcionados às pessoas interessadas em trabalhar com os portadores de necessidades especiais. Na cidade de Salvador, por exemplo, existe apenas uma Universidade que disponibiliza um curso pedagógico específico para esta seara - a UNIME (União Metropolitana de Educação e Cultura).

Ademais, as próprias instituições do Sistema S - Serviço Nacional de Aprendizagem, como o SENAC (Serviço Nacional de Aprendizagem Comercial), que também possuem cotas a serem cumpridas, têm dificuldades para encontrar portadores de deficiência com escolaridade suficiente para qualificá-los e capacitá-los para o mercado de trabalho.

(...)

Logo, a educação, a qualificação, habilitação e reabilitação são imprescindíveis para colocar o portador de necessidade especial no mercado de trabalho. Até porque, a própria lei estipula a contratação do profissional habilitado para tanto." ${ }^{22}$
\end{abstract}

Desse modo temos, de um lado, a obrigação da empresa de cumprir a cota e, de outro, a ausência de capacitação profissional de portadores de necessidades especiais para atender o mandamento legal. O Estado não fornece meios que possibilitem a capacitação do portador de deficiência, restando à empresa cumprir o papel que é de competência do Poder Público. É comum que empresas invistam em cursos ou parcerias com as instituições do Sistema $S$, para oferecer habilitação a pessoas com deficiência e afastar a incidência das temidas multas administrativas.

No entanto, as dificuldades na formação profissional das pessoas com deficiência surgem antes quando ainda são crianças. Apesar de a nossa Constituição garantir uma educação inclusiva (arts.205, 206, I e 208, III), muitas escolas não possuem profissionais capacitados para lidar com alguns tipos de deficiência nem muito menos estruturas adaptadas para receber esses alunos com necessidades especiais. Para tornar concreto o mandamento constitucional, faz-se necessário uma verdadeira transformação nas escolas desde o treinamento dos professores e implantação de técnicas didáticas até a adaptação dos espaços físicos para que se tornem adequados às pessoas portadoras de deficiência.

Afora a falta de estrutura das escolas, ainda há também muita discriminação às pessoas com deficiência no ambiente escolar. Muitas crianças com deficiência não conseguem ser matriculadas na rede pública ou privada. As escolas entendem que lhes é dado o direito de recusar o aluno vez que é garantido ao portador de deficiência um atendimento especializado

\footnotetext{
${ }^{22}$ COSTA, Maína: O sistema de cotas como meio de inclusão do portador de necessidades especiais no mercado de trabalho - Análise crítica do artigo 93, da Lei 8.213/91. Disponível em:

http://www.revistas.unifacs.br/index.php/redu/article/view/504/346. Acesso em 10 out.2011
} 
preferencialmente na rede regular de ensino. Conforme SILVA (2007), tal alegação não merece prosperar:

\begin{abstract}
"A palavra preferencialmente [...] expressa apenas que o constituinte não tinha, como meta próxima, extinguir o ensino especial, mas sim, possibilitar que, com o desenvolvimento da escola inclusiva, aos poucos, os estudantes daqueles estabelecimentos migrassem espontaneamente para as escolas regulares. Assim, o que a Carta propõe é que a pessoa portadora de deficiência possa escolher entre a escola especial e a regular, mas, em hipótese alguma, permite que o educandário se recuse, sem uma justificativa superlativa, a admitir a pessoa portadora de deficiência tão-somente por causa da sua peculiar condição."23
\end{abstract}

Dessa forma, como medida de longo prazo, há que se defender a educação inclusiva. Ou seja, não deveria haver instituições separadas para as pessoas com deficiência mas sim deveria haver a inclusão dessas pessoas nas instituições de ensino regulares já que através da socialização dessas pessoas com as demais crianças haveria uma eliminação da segregação de preconceitos. A educação de crianças com deficiências em um mundo a parte não pode ser vista como solução pois incentiva estigmas e preconceitos, aumentando diferenças e tornando ainda mais difícil a inclusão dessas pessoas na sociedade. A escola que recebe a toda a sociedade seria um espaço ideal para a superação de intolerâncias. A ideia é que um ambiente escolar que integralize os portadores de necessidades especiais cria um futuro ambiente acolhedor no mercado de trabalho.

A verdade é que a ausência de capacitação educacional e profissional dos portadores de necessidades especiais não é boa nem para a empresa e nem para o próprio portador da deficiência. Para a empresa não é interessante manter no seu quadro de funcionários uma pessoa desabilitada não qualificada para exercer determinada função, o que acaba por comprometer o desenvolvimento da atividade empresarial. Para o portador de deficiência não é interessante servir como um mero objeto de cumprimento de cota, não havendo qualquer superação de suas limitações aniquilando o objetivo da lei.

\title{
IV.III - A não inclusão das pequenas e médias empresas na lei no 8.213/91
}

Conforme se depreende da leitura do art.93 da lei no 8.213/91, somente as empresas com 100 (cem) ou mais empregados estão obrigadas a cumprir a reserva de vagas prevista no dispositivo. Conforme a classificação do IBGE pelo critério do número de empregados as empresas podem ser: microempresas, se possuem até 9 (nove) empregados; pequenas

\footnotetext{
${ }^{23}$ SILVA, Alexandre Vitorino. Direitos a prestações positivas e igualdade: a deficiência São Paulo: LTr, 2007. P. 144.
} 
empresas, as que possuem de 10 (dez) a 49 (quarenta e nove) empregados; médias empresas, de 50 (cinquenta) a 99 (noventa e nove) contratados e grandes empresas, se possuírem mais do que 100 (cem) empregados.

Portanto, a lei vale somente para as grandes empresas. Estatisticamente, no Brasil, as grandes empresas são minoria, sendo a maior parte das empresas médias e pequenas. É certo que as grandes empresas muitas vezes ocupam e assalariam um número expressivo de pessoas, as vezes na casa das dezenas de milhares. Mas elas são minoria, existem em quantidade expressivamente menor no Brasil e são as que exigem maior grau de qualificação para compor os seus quadros.

Em virtude de as grandes empresas exigirem um nível de qualificação mais alto, muitos portadores de deficiência ficam excluídos das oportunidades de emprego por não terem qualificação suficiente, como comentado no item supra. Portanto, para incluir no mercado de trabalho um número maior de pessoas portadoras de necessidades especiais é necessário que se aumente o rol de empresas abarcadas pela legislação. Não faz muito sentido excluir a maior gama de empresas e empregadores existente no país, eximindo-os da obrigação de contratar pessoas com deficiência, se essa inclusão deve ser uma obrigação de toda a sociedade.

Conforme Pastore (2000), no Direito Comparado, o número mínimo de empregados necessário para que uma empresa seja obrigada a reservar vagas é reduzido: na Áustria a reserva deve ser cumprida por empregadores com mais de 25 (vinte e cinco) empregados; na França, esse número é de 20 (vinte); na Alemanha, 16 (dezesseis); no Japão 56 (cinquenta e seis); e na Espanha, 50 (cinquenta). ${ }^{24}$

Podemos notar que o número exigido pela lei brasileira, de 100 (cem) empregados, é demasiado alto para a realidade do país e exclui uma gama imensa de empresas abrangidas pelas cotas legais. A redução desse número ampliaria a extensão da norma e garantiria um acesso maior das pessoas com deficiência ao mercado de trabalho, notadamente em pequenas e médias empresas, que tem historicamente um nível de exigência mais baixo na contratação dos empregados.

A ação afirmativa proposta pela lei é bem vinda, mas em mais esse aspecto se mostra incompleta, no sentido de somente garantir o emprego do portador de deficiência na minoria das empresas, as grandes, deixando de incluí-lo nas demais. A lei deixou de dar, portanto,

\footnotetext{
${ }^{24}$ PASTORE, José. Oportunidades de trabalho para portadores de deficiência. São Paulo: LTr, 2000. P. 165-169.
} 
efetividade à norma constitucional que veda a recusa de emprego ao portador de deficiência unicamente pela sua deficiência (art.7으, XXXI, CF/88).

O dispositivo supra é norma constitucional de conteúdo programático e eficácia limitada e, como tal, necessita de legislação futura. No entanto, o dispositivo produz efeitos jurídicos imediatos, independentemente de regulação já que estabelece um dever ao legislador infraconstitucional: condiciona a legislação futura sobre o tema e macula de inconstitucionalidade leis ou atos que a ofendam. Além disso, é norma que informa a sociedade a sua própria concepção, fixando fins sociais e condicionando a interpretação de toda a legislação bem como de sua aplicação pelo Executivo, Legislativo e Judiciário. A lei no 8.213 em seu art.93 não efetivou de forma plena o referido dispositivo da Constituição, motivo pelo qual, podemos entender que a norma sofre de inconstitucionalidade por omissão.

Dito isso, cabível seria uma ação direta de inconstitucionalidade por omissão para que fosse decretada a omissão legislativa para, em seguida, a Justiça estipular um prazo para o suprimento da omissão diante da inércia do Poder legiferante. Situação semelhante ocorreu, recentemente, com o dispositivo constitucional que prevê o aviso prévio proporcional ao tempo de serviço (art.7으, $\mathrm{XXI}, \mathrm{Cf} / 88$ ), que há vinte e três anos aguardava uma regulação que veio finalmente com a lei 12.506/11 que entrou em vigor no dia 13 de outubro de 2011. Diante da ameaça do Supremo Tribunal Federal de regular o aviso prévio proporcional mediante decisão judicial que teria efeito erga omnes, o Legislativo se apressou e aprovou uma lei que regulamentasse a questão quase que a toque de caixa.

\section{IV.IV - A falta de incentivos econômicos}

Existe no Brasil uma ideia recorrente de que os próprios entes privados devem suportar os ônus das ações afirmativas impostas pelo Poder Público. No entanto, é interessante a discussão de o Estado poder fornecer incentivos ao setor privado quando se trate de contratação de pessoas com deficiência, visto que apesar do aparato legal protetivo existente, o grupo de pessoas com deficiência ainda tem uma participação no mercado de trabalho muito aquém do que seria o ideal. Um dos motivos (Pastore, 2000), não resta dúvidas, é a "carência de ações, estímulos e instituições que viabilizem, de forma concreta, a formação, habilitação e inserção dos portadores de deficiência no mercado de trabalho" ${ }^{25}$

\footnotetext{
${ }^{25}$ PASTORE, José. Oportunidades de trabalho para portadores de deficiência. São Paulo: LTr, 2000. P. 59.
} 
Uma forma de superação do problema, portanto, seria a implantação de políticas públicas de incentivos fiscais. A redução da carga tributária ou das contribuições previdenciárias consistem em importante incentivo a empregabilidade desse grupo minoritário. São medidas de fácil execução e que acabariam dando efetividade ao direito ao trabalho que estas pessoas possuem.

Gugel (2007) aponta exatamente a redução de alíquotas ou bases de cálculo de encargos como medidas de incentivo

“A Constituição da República prevê para o financiamento da seguridade social a possibilidade de alíquotas ou bases de cálculo diferenciadas (Art. 195, § $9^{\circ}, \mathrm{CF} / 88$ ) em razão da atividade econômica ou da utilização intensiva de mão-de-obra para o empregador ou empresa incidentes sobre folha de salários, receita e lucro. A redução de alíquotas de encargos sociais, por exemplo é uma possibilidade já praticada no mundo do trabalho, cuja demonstração mais recente é a alíquota reduzida de recolhimento do FGTS nos contratos de aprendizagem, com previsão na Lei 10.097/2000”26

Além disso, a adoção dessas medidas de estímulo fiscal também incentivaria a contratação em empresas não obrigadas a contratar pessoas com deficiência, como aquelas que possuem menos de 100 (cem) empregados, expandindo o âmbito de influência da lei.

Um outro exemplo de incentivo fiscal que tenta ver a luz do dia é o Projeto de Lei no 470/2011 (autoria do Deputado Federal Inocêncio Oliveira - PE) que tramita na Câmara dos Deputados. O Projeto concede incentivo fiscal à empresa privada que contratar presos dos regimes fechado, semiaberto ou ex-presos. Pelo projeto, a empresa fica isenta da contribuição social sobre a folha de pagamento relativa a essa contratação. Ao mesmo tempo, o projeto prevê reserva de vagas na Administração Pública para essas pessoas.

Também há em tramitação na Câmara um Projeto de Lei (Projeto de Lei 5977/2009 de autoria do Deputado Federal Valdir Colatto - $\mathrm{PMDB} / \mathrm{SC}$ ) que concede incentivo fiscal do imposto sobre renda às pessoas jurídicas que contratarem pessoas com mais de sessenta anos. A proposição apresenta que a pessoa jurídica tributada com base no lucro real poderá deduzir, do imposto devido, os dispendias efetivamente realizados com a contratação e manutenção de empregados acima dessa faixa etária. O Projeto busca incentivar as empresas a contratar idosos tendo em visto a melhora de qualidade de vida dessas pessoas que muitas vezes são dispensadas ou não são contratadas por preconceito já que com o aumento da expectativa de vida muitas pessoas acima de sessenta anos ainda se encontram com condições físicas e mentais totalmente adequadas ao exercício de diversas tarefas.

\footnotetext{
${ }^{26}$ GUGEL, Maria Aparecida. Pessoas com deficiência e o direito ao trabalho. Florianópolis: Obra jurídica, 2007. P. 61.
} 
Existem muitos outros projetos já apresentados tanto na Câmara quanto no Senado que buscam criar incentivos à contratação de minorias, como os jovens, idosos, ex-presos e até mulheres solteiras. Existe inclusive projetos que tentam criar incentivos fiscais para empresas que contratem pessoas como deficiência, como o projeto 3470/2008 do Deputado Dr. Talmir (PV/SP) que cria o Programa Empresa Consciente e dispõe sobre incentivos a empresas que adotarem determinadas práticas desejáveis pelo Estado, como respeito ao meio ambiente e contratação de ex-usuário de drogas, presidiários e pessoas portadoras de deficiência. Porém, nenhuma desses projetos jamais chegou sequer perto de virar lei.

No entanto, como podemos notar, já há uma ideia consolidada na sociedade de que incentivos fiscais exercem algum efeito sobre as decisões dos empreendedores. Não é por outro motivo que eles são utilizados para estimular atitudes desejadas pelo Estado e pela sociedade. O incentivo fiscal, nesse sentido, sinaliza o empenho governamental e o interesse da sociedade na implementação do benefício que lhe é subjacente.

Por derradeiro, deve-se ressaltar que as empresas, para receber deficientes físicos em suas instalações, necessitam fazer adaptações em seus ambientes como a construção de rampas, banheiros com cabines mais espaçosas e elevadores para cadeirantes além de ter de adquirir materiais ou equipamentos especiais para permitir que pessoas com deficiência possam trabalhar em algumas funções. Tudo isso representam custos que não sofrem qualquer tipo de incentivo por parte do Poder Público, sejam incentivos fiscais ou incentivos na forma de financiamentos públicos para a realização das adaptações necessárias.

\section{IV.V - A inexistência de regras para a (re)colocação no mercado de trabalho}

Cada pessoa com deficiência possui habilidades e talentos específicos, assim como qualquer outra pessoa. No momento de contratar ou de promover, o empregador compara as competências que cada candidato possui com as atribuições exigidas pelo cargo pretendido.

Porém, como já foi mencionado supra, a lei não prevê nenhum tipo de distinção com relação à atividade a ser desenvolvida pelo empregado. O empregador, dessa forma, não dá atenção às qualificações do candidato com deficiência ao ver aquele sujeito apenas como portador de deficiência, de forma taxativa, como faz a lei, como se todos fossem iguais, inclusive em suas competências. Dessa forma, tornou-se comum o hábito de a empresa reunir todas as pessoas portadoras de deficiência em uma única função, como já mencionado nesse trabalho, por entender que aquela função é a mais adequada àquele tipo de deficiência. Dessa maneira, é comum a associação de certos tipos de deficiências com algumas determinadas 
tarefas, questão nem de longe tangenciada pela taxativa cota do art.93. É comum, por exemplo, a associação dos deficientes auditivos com o trabalho em almoxarifados, a dos visuais com telefonia e os físicos ao teleatendimento. Tal correlação é restritiva e é certo que esse não é o fim pretendido pela lei. E mais certo ainda, não é uma forma eficaz de inserção da pessoa portadora de deficiência no mercado de trabalho.

\begin{abstract}
“Não existem profissões para pessoas que têm determinadas deficiências. Existem profissionais com deficiência que têm habilidades para diversas funções ocupacionais. É claro que não se pode pensar em um motorista cego, ou em telefonistas surdos...Por isso é que, como com qualquer outra pessoa, há que se avaliar suas competências e habilidades e verificar qual(is) função(ões) ocupacional(is) para se fazer uma colocação de sucesso. [...] Atenção e concentração também não são habilidades inerentes à condição de surdez. Na realidade os índices de atenção e concentração da pessoa surda apresentam-se no mesmo padrão encontrado em pessoas ouvintes. Os ouvintes se equivocam nessa questão, ao acreditar que uma pessoa surda pode muitas vezes trabalhar em ambientes ruidosos, sem se dispersar da atividade que estão desenvolvendo. Não se pode, entretanto, esquecer, que a experiência tem revelado que outros estímulos, não sonoros, também podem provocar a dispersão da atenção da pessoa surda. [...] A pessoa não terá uma maior sensibilidade, ou um ouvido absoluto, só porque é cega. Ela apenas estará com sua atenção mais voltada aos estímulos sonoros."27
\end{abstract}

Para evitar esse tipo de prática discriminatória, o ideal seria que as empresas possuíssem critérios objetivos para a admissão e ascensão profissional, apontando quais são as habilidades exigidas para um determinado cargo ou função. Empresas mais modernas tem em suas políticas de Recursos Humanos instrumentos como Planos de Cargos e Salários e Descrição de Cargos e Funções que facilitam a apuração dessas questões. Com esses instrumentos presentes é mais fácil de se detectar quando ocorre uma discriminação.

Se, por exemplo, uma pessoa tem todas as habilidades exigidas para o exercício de determinada função que está vaga na empresa e a empresa o contrata para ocupar outro posto que não aquele, a empresa pode estar cometendo um ato discriminatório. Admitir um empregado com deficiência em uma função completamente diversa daquela relacionada à sua formação profissional ou acadêmica causa no contratado um sentimento de injustiça, desrespeito e exclusão e denota uma atitude discriminatória. O empregador que atua dessa forma não contribui para a inclusão da pessoa portadora de deficiência.

As empresas, não raro, agem de forma discriminatória apenas porque adotam a postura de cumprir a cota de deficientes, formalmente. Mas não cumprem a real finalidade da norma. Não basta admitir portadores de deficiência mas é necessário contratá-los para cargos

\footnotetext{
${ }^{27}$ PRESIDÊNCIA DA REPÚBLICA. Secretaria Especial dos Direitos Humanos. Construindo um mercado de trabalho inclusivo: Guia prático para profissionais de recursos humanos, por Tais Suemi Nambu. Brasília, 2003.
} 
compatíveis com as suas possibilidades e qualificações e oferecer a eles as mesmas oportunidades de ascensão que são oferecidas aos demais candidatos.

Portanto, podemos notar que o art.93 da lei falhou mais uma vez ao prever somente a obrigatoriedade da reserva de vagas para pessoas com deficiência sem prever nenhum tipo de critério ou diferenciação para a admissão desses empregados. O único critério apresentado pela lei é o do portador de deficiência ser habilitado. É uma previsão que protege interesses do empregadores, reconheça-se, mas não garante a admissão do portador de deficiência a uma vaga que seja condizente com a suas limitações. Mais uma vez podemos entender que a lei sofre de inconstitucionalidade por omissão ao não garantir o direito constitucional previsto no art.7으, XXXI da Constituição que prevê a não discriminação para a admissão no mercado de trabalho.

Na Administração Pública, por seu turno, há uma reserva de vagas nos concursos e o candidato escolhe para qual vaga deseja concorrer. Aqui a lógica é diferente visto que o candidato tem a liberdade de escolher para qual cargo deseja concorrer. Obedece-se o art.5으, XIII da Constituição Federal de 1988 que trata da liberdade no exercício da profissão. A Administração, e não poderia ser diferente, obedece a critérios rígidos e objetivos acerca das qualificações exigidas para os cargos objetos de concurso público. O processo seletivo tem provas e títulos e algumas vezes estágios probatórios, que possuem requisitos de aprovação previstos em lei. Dessa forma, temos objetividade e transparência na escolha dos candidatos, dificultando eventuais discriminações. Algo semelhante poderia ser adotado pela lei 8.213/91 de modo a evitar discriminações e a estimular a correta colocação ou recolocação da pessoa com deficiência no mercado de trabalho. 


\section{CONCLUSÃO}

Este trabalho buscou promover e estimular a discussão sobre a reserva de vagas prevista no art. 93 da lei 8.213/91. Como deve ter ficado claro ao leitor, o trabalho não se posiciona contra ações afirmativas, muito pelo contrário. As ações afirmativas, como as reservas de vagas, estão em perfeita consonância com a nova ideia de igualdade, como defendemos. $O$ tratamento desigual de pessoas eminentemente desiguais é não só admitido como incentivado pelo Direito e pela mais iluminada doutrina.

Contudo, apesar de merecer elogios, a reserva de vagas em comento, encontra, na dura realidade do mercado de trabalho, uma série de dificuldades para se tornar realidade. 0 cumprimento da "cota de deficientes" pura e simplesmente não atinge os fins pretendidos pela lei. Ou seja, o cumprimento da lei não garante a inserção do portador de deficiência no mercado de trabalho na medida em que a lei não vai além da reserva de vagas, como vimos.

Além disso, muitas vezes a lei não pode ser cumprida por razões que fogem a vontade do empregador. Questão também nem de longe mencionada ou tratada pela nossa legislação.

O Estado se mostra omisso nos programas de habilitação, reabilitação e capacitação de portadores de necessidades especiais. Os poucos programas que existem se mostram insuficientes a realidade brasileira. Notamos também a ausência ou raridade de cursos profissionalizantes direcionados a esse público e aos professores e educadores que irão capacitá-los. O Poder Executivo tem deixado a desejar nas iniciativas que visam a inclusão de deficientes no mercado de trabalho, restando ao empregador tentar preencher essa lacuna criando ele mesmo cursos e treinamentos para esse público minoritário.

Vimos que além da falta de ação do Executivo, o Legislativo também pecou. As leis existentes, notadamente a 8.213/91, não se mostram suficientes diante da complexa realidade do problema. Apontamos na lei algumas lacunas, pontos obscuros e incongruências que dificultam, generalizam e em nada contribuem para facilitar a inclusão dos portadores de necessidades especiais no mercado de trabalho. 0 dispositivo do art.93 se mostra taxativo e genérico demais, não endereçando todas as questões relacionadas ao problema da empregabilidade da pessoa com deficiência.

O dispositivo ora em comento não evita discriminações na admissão e na promoção de empregados. Da mesma forma, não determina nenhum tipo de obrigação para empresas com menos de 100 (cem) empregados, o que criticamos e sugerimos a mudança legislativa no sentido de diminuir essa "linha de corte" para se aumentar as empresas abarcadas pela norma. 
De outro modo, a lei não diferencia as empresas por ramos de atividade, colocando no mesmo "bolo" empresas tão díspares como supermercados atacadistas e empresas de serviços de consultoria de informática. O resultado é que muitas empresas não conseguem, apesar de todos os hercúleos esforços alvidrados nesse sentido, cumprir a lei. Não por incompetência e talvez nem por falta de profissionais no mercado, mas por uma absoluta incompatibilidade entre, de um lado, a atividade preponderantemente exercida pela empresa e as qualificações e capacitações inerentemente exigidas e, de outro lado, as pessoas portadoras de necessidades especiais.

A inclusão de pessoas com deficiência no mercado de trabalho também esbarra em obstáculos como as exigências das empresas versus a falta de qualificação dos portadores de deficiência. A lei não faz nenhum controle por parte da qualificação a ser exigida pela empresa e nem muito menos faz alguma previsão sobre a obrigação estatal de capacitar e habilitar essas pessoas, relegando a tarefa mais uma vez à iniciativa privada. Sugerimos que o Estado tome para si essa responsabilidade de qualificar e capacitar tanto as pessoas com deficiência como os professores e educadores que irão capacitá-los.

A norma também não faz nenhum tipo de diferenciação entre as atividades a serem desempenhadas pelo portador de deficiência. Um tema delicado, por certo, já que os autos denominados politicamente corretos, tão em voga nos dias de hoje, podem entender tal tema como discriminação, mas não entendemos dessa forma. Entendemos que é necessário sim haver essa previsão de modo que o portador de deficiência possa exercer funções e atividades compatíveis com as suas limitações. É uma proteção inclusive para o próprio portador de necessidade especial tendo em vista que a lei enxerga todos da mesma forma o que acaba contribuindo para que o empregador faça o mesmo e não atente para as peculiaridades e necessidades de cada um. O resultado é a já conhecida prática de colocar todos os portadores de deficiência para exercer uma mesma função dentro da empresa, em nada contribuindo para incluir esse grupo no mercado de trabalho de forma efetiva mas sim contribuindo para reforçar a discriminação. O que acaba ocorrendo é que as pessoas com deficiência são contratadas para ocupar funções totalmente diversas daquelas para as quais se habilitaram ou então são contratadas para ocupar cargos inferiores àqueles que poderiam ocupar tendo em vista suas habilidades e capacidades.

Para que a ação afirmativa prevista na lei tenha seu fim atingido é necessário que o portador de deficiência seja incluído no mercado de trabalho. Para tal, não basta contratá-lo. É necessário que esse trabalhador exerça uma função condizente com suas capacitações para 
que possa ocorrer com pé de igualdade com todos os seus colegas de trabalho, tendo assim chances de promoção e ascensão profissional. As leis existentes deixam de reconhecer essa questão e nem mesmo comentam sobre a promoção e ascensão de portadores de necessidades especiais, importantes meios de inclusão dessas pessoas no mercado de trabalho. É necessário e sugerimos que a lei se preocupe com essas questões para dar maior efetividade aos fins propostos.

Por fim, reconhecemos que modificações legais não bastam para mudar a realidade social, apesar de serem um importante estímulo. É necessário que outra ações sejam tomadas em conjunto de modo que cheguemos ao fim pretendido da inclusão das pessoas com deficiência no mercado de trabalho e emprego. A sociedade e os empregadores necessitam de uma maior conscientização sobre a questão; devem ser feitos maiores investimentos na formação e qualificação de pessoas com deficiência; devem ser adotados estímulos econômicos às empresas para que contratem essas pessoas e desenvolvam programas de habilitação e capacitação além de promoverem a acessibilidade dos locais de trabalho; incentivos para que as empresas habilitem todos os empregados para que aprendam a lidar com todo tipo de deficiência; e o Poder Público deve chamar para si a responsabilidade de incluir e respeitar essas pessoas, promovendo a igualdade de oportunidades da forma mais proporcional possível. 


\section{REFERÊNCIAS BIBLIOGRÁFICAS}

COMPARATO, Fábio Konder. Direito público: estudos e pareceres. São Paulo: Saraiva, 1996.

COSTA, Maína: O sistema de cotas como meio de inclusão do portador de necessidades especiais no mercado de trabalho - Análise crítica do artigo 93, da Lei 8.213/91. Disponível em: <http://www.revistas.unifacs.br/index.php/redu/article/view/504/346>. Acesso em 10 out. 2011.

CUNHA JUNIOR, Dirley da. Controle Judicial das Omissões do Poder Público: em busca de uma dogmática constitucional transformadora à luz do direito fundamental à efetivação da Constituição. São Paulo: Saraiva, 2004.

FEBRABAN. População com deficiência no Brasil - fatos e percepções. Coleção Febraban de inclusão social: 2006.

GOMES, Joaquim Barbosa. Ação afirmativa e princípio constitucional da igualdade. Rio de Janeiro: Renovar, 2001.

GUGEL, Maria Aparecida. Pessoas com deficiência e o direito ao trabalho. Florianópolis: Obra Jurídica, 2007.

MELLO, Celso Antonio Bandeira de. Conteúdo jurídico do princípio da igualdade. 3 Ed. São Paulo: Malheiros, 2002.

MENDES, Gilmar. Curso de Direito Constitucional. 2ª ed. São Paulo: Saraiva, 2008.

MINISTÉRIO DO TRABALHO E EMPREGO. Observatório do Mercado de Trabalho Nacional Boletim de Indicadores do Mercado de Trabalho. Brasília, 2010. Disponível em http://www.mte.gov.br/observatorio/indicadores_boletim_03.pdf . Acesso em 03 out. 2011.

MORAES, Alexandre de. Direito Constitucional. São Paulo: Atlas, 2006.

PASTORE, José. Oportunidades de trabalho para portadores de deficiência. São Paulo: LTr, 2000.

PRESIDENCIA DA REPÚBLICA. Secretaria Especial dos Direitos Humanos. Trabalho e Emprego: Instrumento de Construção da Identidade Pessoal e Social, por Maria Salete Fábio Aranha. Brasília, 2003. Disponível em <http://www.mj.gov.br/corde/>. Acesso em 30 nov. 2009. 
PRESIDÊNCIA DA REPÚBLICA. Secretaria Especial dos Direitos Humanos. Construindo um mercado de trabalho inclusivo: Guia prático para profissionais de recursos humanos, por Tais Suemi Nambu. Brasília, 2003.

ROCHA, Carmen Lúcia Antunes. Ação afirmativa - o conteúdo democrático do princípio da igualdade jurídica. Revista Trimestral de Direito Público, São Paulo, n. 15, 1996.

SILVA, Alexandre Vitorino. Direitos a prestações positivas e igualdade: a deficiência São Paulo: LTr, 2007. 